Wojciech Kordyzon

https://orcid.org/oooo-0002-429I-886X

Uniwersytet Warszawski

\title{
Mleko duchowne - Upominek od Pietra Paola Vergeria w polskim przekładzie Ostafiego Trepki z 1556 roku*
}

Artykuł służy przedstawieniu polskiego wydania z 1556 r. katechetycznego utworu skierowanego do dzieci znanego jako Mleko duchowne, którego łacińską wersję zredagował Pietro Paolo Vergerio. W pierwszej części zaprezentowano informacje bibliograficzne na temat druku oraz właściwości tekstu polskiego, a także omówiono kwestię adresatów spolszczenia oraz funkcjonalności zastosowanych $\mathrm{w}$ nim rozwiązań typograficznych. W części drugiej przedstawiono transkrypcję tekstu wraz z komentarzem językowym i podano szczegółowe zasady wydania.

The article presents the Polish edition of the 1556 catechetical instruction addressed to children known as the Spiritual Milk; its Latin version was edited by Pietro Paolo Vergerio. The first part contains bibliographical information about the printing and the characteristics of the Polish text. It also discusses the question of the audience of the translation and the functionality of its typographical solutions. The second part presents a transcription of the text together with a linguistic commentary and a detailed account of the applied transcription rules.

* Badania przedstawione $\mathrm{w}$ artykule zostały przeprowadzone $\mathrm{w}$ ramach projektu badawczego Więcej niż propaganda. Polskojęzyczny program wydawniczy w Królewcu jako projekt edukacji religijnej i kulturalnej (ok. 1544-1575), finansowanego przez Narodowe Centrum Nauki, nr 2020/37/N/HS2/00467. 
Słow a klu c zow e: Królewiec, Prusy Książęce, Ostafi (Eustachy) Trepka, Pietro Paolo Vergerio, Juan Valdés, katechizm, Aleksander Aujezdecki (Augezdecki)

Ke yw o rd s: Königsberg, Ducal Prussia, Ostafi (Eustachy) Trepka, Pietro Paolo Vergerio, Juan Valdés, catechism, Alexander Aujezdecki (Augezdecki)

Polski przekład Mleka duchownego, czyli katechizmu przeznaczonego dla dzieci, ułożonego pierwotnie przez Juana Valdésa, a następnie opracowanego przez Pietra Paola Vergeria, ukazał się w 1556 r. w oficynie Aleksandra Aujezdeckiego (Augezdeckiego) ${ }^{1}$. Przedrukowano go w XIX stuleciu dwukrotnie. Najpierw tekst znalazł się w paralelnej edycji różnojęzycznych wersji utworu Valdésa, którą sporządził Edward Böhmer ${ }^{2}$, a następnie ze względu na błędy w transliteracji podanej przez niemieckiego uczonego nową opracował Jan Karłowicz i ogłosił w „Pracach Filologicznych”. Obaj badacze opierali się na jedynym ówcześnie znanym egzemplarzu druku w polskim przekładzie, który należał do zbiorów Staats- und Universitätsbibliothek Königsberg. Był to również jedyny egzemplarz, jaki znał Karol Estreicher ${ }^{4}$. Po zawierusze drugiej wojny światowej książkę długo uznawano za zaginioną ${ }^{5}$. Informację o egzemplarzu przechowywanym w Geheimes Staatsarchiv Preussischer Kulturbesitz w Berlinie w uzupełnieniu do Bibliografii polskich druków ewangelickich Władysława Chojnackiego podała Małgorzata Szymańska-Jasińska dopiero pod koniec ubiegłego wieku' ${ }^{6}$ Tę samą informację uwzględniła potem

1 [J. de Valdés, P. P. Vergerio], Upominek, który Vergerius jasnemu panu Mikotajowi [--] postat - Mlieko duchowne dla karmienia i wychowania chrześsijańskich dziatek ku chwale boskiej, tł. O. Trepka, Królewiec 1556 (VD 16: V 672). Tu i dalej wszystkie numery Verzeichnis der im deutschen Sprachbereich erschienenen Drucke des 16. Jahrhunderts (dalej: VD 16) za wydaniem online: http://www. vd16.de (25 XII 2020).

2 J. de Valdés, Instrucion cristiana para los niños por Juan de Valdés en ocho lenguas / Christliche Kinderlehre, hrsg. E. Böhmer, Bonn 1883.

3 J. Karłowicz, Mleko duchowne z r. 1556, „Prace Filologiczne”, 1, 1885, s. 404-433.

4 Zob. K. Estreicher, Bibliografia polska, t. 32, Kraków 1938, s. 160.

5 Zob. W. Chojnacki, Bibliografia polskich druków ewangelickich Ziem Zachodnich i Pótnocnych 1530-1939, Warszawa 1966, s. 190, nr 2160; P. Buchwald-Pelcowa, Aleksander Augezdecki. Królewiec - Szamotuty, 1549-1561(?), Wrocław 1972 (Polonia Typographica Saeculi Sedecimi, t. 7), s. 70.

6 W. Chojnacki, M. Szymańska-Jasińska, Uzupetnienie do „Bibliografii polskich druków ewangelickich Ziem Zachodnich i Pótnocnych 1530-1939”, „Komunikaty Mazursko-Warmińskie”, 1997, 2, s. 282, nr 2160. 
także Vanessa Bock ${ }^{7}$. Wolumen z berlińskiego archiwum ma pieczęć własnościową dawnej królewieckiej biblioteki - jest to więc ten sam egzemplarz, z którego korzystali wcześniejsi badacze. $\mathrm{Na}$ jego podstawie sporządzono również prezentowaną tu edycję utworu. Tekst warto opracować ponownie, ponieważ wydanie J. Karłowicza zawierało jedynie transliterację (podczas gdy w polskiej literaturze naukowej coraz powszechniej stosuje się transkrypcję), którą obudowano jedynie rudymentarnymi, właściwymi wydaniom dziewiętnastowiecznym, objaśnieniami.

Utwór Valdésa powstał przypuszczalnie w latach czterdziestych XVI w. w języku hiszpańskim, w którym zazwyczaj pisał ten autor nie jest jednak znany odautorski przekaz tekstu ani w rękopisie, ani w druku ${ }^{8}$. W jakiejś formie - zapewne po włosku - tekst musiał funkcjonować przed 1549 r., zbliżony tytuł pojawia się bowiem na indeksie prohibitów z tego roku9. Pierwsze znane materializacje tekstu to książki w języku włoskim. Nie noszą one nazwiska Valdésa ani nie ujawniają tożsamości hipotetycznego tłumacza. Wiadomo o dwóch przypuszczalnie najwcześniejszych - włoskojęzycznych drukach bez miejsca i daty wydania, a także dwóch kolejnych, już sygnowanych, z Bazylei z 1549 r. oraz z Pawii z 1550 r. ${ }^{10}$

Następnie Vergerio przetłumaczył katechizm Valdésa na łacinę, opatrując go własnym nazwiskiem, i wydał w Tybindze, w oficynie Ulricha Morharta w 1554 r., określając utwór w tytule jako „podarek” (łac. munusculum) dla Eberharda (1545-1568), syna Krzysztofa,

7 V. Bock, Die Anfänge des polnischen Buchdrucks in Königsberg. Mit einem Verzeichnis der polnischen Drucke von Hans Weinreich und Alexander Augezdecki, w: Königsberger Buch- und Bibliotheksgeschichte, hrsg. A. E. Walter, Köln 2004, s. 155 .

8 Zob. J. C. Nieto, Juan de Valdés on Catechetical Instruction. The Dialogue on Christian Doctrine and the Christian Instruction for Children, „Bibliothèque d'Humanisme et Renaissance", 36, 1974, 2, s. 254; E. Böhmer, Bibliotheca Wiffeniana. Spanish Reformers of Two Centuries from 1520, vol. 1, Strassburg 1874, s. 71-72. Atrybucję autorską katechizmu dyskutowano jeszcze w XIX w. (zob. ibidem, s. 71, przyp. 12).

9 Zob. E. Böhmer, Bibliotheca Wiffeniana, s. 122.

10 [J. de Valdés, P. P. Vergerio], Lacte spirituale, col quale si debbono nutrire e allevare $i$ figliuoli de christiani in gloria di Dio, Basilea 1549 (EDIT 16: CNCE 72343); [iidem], Latte spirituale, col quale si debbono nutrire e allevare i figliuoli de Christiani in gloria di Dio, Pavia 1550 (EDIT 16: CNCE 80405). Tu i dalej numery Censimento nazionale delle edizioni italiane del XVI secolo (EDIT 16) za wydaniem online: http://edit16.iccu.sbn.it (25 XII 2020); zob. też J. de Valdés, Instrucion cristiana, s. X-XII. 
księcia Wirtembergii (1515-1568) ${ }^{11}$. Znamienne, że Vergerio, przedrukowując tekst wydawany wcześniej bez nazwiska Valdésa, nie przedstawił siebie jako autora, jak czasem się sugeruje, ale pozostawił w swego rodzaju niedopowiedzeniu jako osobę przekazującą tytułowy podarunek. Dopiero w drugim wydaniu łacińskim ${ }^{12}$, mocniej zmodyfikowanym przez Vergeria, które wyszło u Hansa Daubmanna w Królewcu, wykorzystano na stronie tytułowej łaciński odpowiednik (Lac spirituale) tytułu występującego we wcześniejszych włoskojęzycznych edycjach utworu (Latte| Lacte spirituale). Książka tłoczona przez Daubmanna wyszła bez daty. Jan Karłowicz uznawał, że musiało to być „prawie równocześnie, jak się zdaje” z wydaniem tybińskim $^{13}$, a zatem ok. 1554 r. Natomiast K. Estreicher wszystkie znane mu egzemplarze łacińskiej wersji sygnowane przez Daubmanna datował na rok $1556^{14}$, przyjmując, że książka nie mogła wyjść później niż przekład polski, który przeważnie oparty został na redakcji znanej z owego wydania królewieckiego (choć nieliczne ustępy, jak wskazał J. Karłowicz, świadczą o znajomości także pierwszego wydania łacińskiego, któremu przekład polski bywa okazjonalnie bliższy) ${ }^{15}$. W efekcie brak jednoznacznych wiadomości o drugim wydaniu łacińskim doprowadził do pewnych niejasności, gdyż Esther-Beate Körber w swojej monografii zinterpretowała obie daty jako świadectwo osobnych wydań. Jest to jednak niemożliwe, ponieważ i J. Karłowicz, i K. Estreicher uznali jedyny znany dzisiaj egzemplarz z Herzog August Bibliothek w Wolfenbüttel oraz niezachowane egzemplarze Biblioteki Tarnowskich w Dzikowie i Ordynacji Krasińskich za

11 [J. de Valdés, P. P. Vergerio], Illustri atque optimae spei puero Eberhardo, illustrissimi principis et domini, domini Christophori Ducis Wirtembergensis etc., filio primogenito, munusculum Vergerii exulis Iesu Christi, [Tübingen] 1554 (VD 16: ZV 18320).

12 [Iidem], Lac spirituale pro alendis ac educandis Christianorum pueris ad gloriam Dei. Munusculum Vergerii [--] Domino Nicolao, [--] principis D. Nicolai Radivili [--] primogenito. Adiecta sunt: Prima christianae religionis elementa [--] per Andream Tricesium [--] et Mathiam Stoium, Königsberg [1554-1556?] (VD 16: T 2151). Wspomnianych w tytule rzekomo współwydanych utworów Andrzeja Trzecieskiego i Matthiasa Stojusa prawdopodobnie nigdy nie wydrukowano (a przynajmniej nie odnaleziono nigdy żadnych egzemplarzy ani wzmianek o nich); zob. J. Karłowicz, op. cit., s. 417; J. Krókowski, Wstęp, w: A. Trzecieski, Carmina. Wiersze tacińskie, oprac. J. Krókowski, Wrocław 1957, s. XXV.

13 Zob. J. Karłowicz, op. cit., s. 416.

14 Zob. K. Estreicher, op. cit., s. 159.

15 Zob. J. Karłowicz, op. cit., s. 418-419. 
warianty tego samego wydania (książka z Augusty różniła się od tych znanych z kolekcji w Polsce tylko drobnymi korektami, które zazwyczaj wprowadzano już w trakcie drukowania jednego nakładu) ${ }^{16}$.

Zagadnienie dodatkowo komplikuje fakt, że niedatowane łacińskie wydanie królewieckie zawiera w kolofonie informację, że ukazać się miały równoległe także przekłady niemiecki i polski ${ }^{17}$. Uwaga ta mogła jednak odnosić się tak do książki już wydanej, jak i przygotowywanej do druku, a jeszcze pozostającej w rękopisie. O ile jednak istnienie tłumaczenia polskiego nie pozostawia wątpliwości, o tyle odniesienie do przekładu niemieckiego nie jest całkiem jasne. Jan Sembrzycki sądził, że mowa tu o tybińskim wydaniu Morharta z 1555 r. $^{18}$, ponieważ jest to jedyne znane niemieckie tłumaczenie utworu $\mathrm{z}$ owego czasu.

Cechy tekstu wydania polskiego były już omawiane przez J. Karłowicza, choć warto je ogólnie przypomnieć i uzupełnić1 ${ }^{19}$. Tłumaczem tekstu polskiego z druku Aujezdeckiego z 1556 r. był Ostafi (Eustachy) Trepka, aktywny w Królewcu i Wielkopolsce działacz luterański $^{20}$. Ten rzutki kaznodzieja zapisał się przede wszystkim jako tłumacz wielu dzieł na język polski, tak na potrzeby luterańskiej edukacji religijnej w Prusach (katechizmów czy postyll), jak i tekstów eksportowanych poza księstwo, rozpowszechnianych w celu agitacji konfesyjnej, nieraz samodzielnie przezeń kolportowanych ${ }^{21}$. W lipcu $1556 \mathrm{r}$.

16 Zob. K. Estreicher, op. cit., s. 159; J. Karłowicz, op. cit., s. 417; por. E.-B. Körber, Öffentlichkeiten der frühen Neuzeit. Teilnehmer, Formen, Institutionen und Entscheidungen öffentlicher Kommunikation im Herzogtum Preussen von 1525 bis 1618, Berlin 1998, tab. po s. 424 (Verzeichnis der Drucke), s.v. Vergerio, Lac spirituale.

17 [J. de Valdés, P. P. Vergerio], Lac spirituale, k. b 3 rec.: „Ex Italico, versus est etiam Germanice et Polonice".

18 [Idem], Ein edel schriftlich Kleinath und Verehrung, tł. B. Hagen, Tübingen 1555 (VD 16: V 671); zob. J. Sembrzycki, Die Reise Vergerius nach Polen 1556-1557, sein Freundkreis und seiner Königsberger Flugschriften aus dieser Zeit, Königsberg 1890, s. 52.

19 Zob. J. Karłowicz, op. cit., s. 415-418.

20 Działalność Trepki podsumowana została w monograficznym artykule T. Wotschkego, Eustachius Trepka. Ein Prediger des Evangeliums in Posen, „Zeitschrift der Historischen Gesellschaft für die Provinz Posen”, 18, 1903, s. 87-144; zob. też G. Ziaja, Lexikon der bedeutendsten Protestanten in Polen-Litauen im 16. Jahrhundert, Warszawa 2016, s. 152-153.

${ }^{21} \mathrm{Na}$ temat jego działalności jako tłumacza zob. też G. Jurkowlaniec, Postylle Arsatiusa Seehofera i Antona Corvinusa w przektadzie Eustachego Trepki. Addenda et corrigenda do badań nad poczatkami postyllografii w języku polskim, „Terminus", 22, 2020, 1(54), s. 1-17; W. Kordyzon, Rzymskie korzenie herezji. Stowo 
pisarz przypuszczalnie przywitał w Poznaniu Vergeria zmierzającego dalej do Królewca i Wilna, a zatem obaj reformatorzy najpewniej znali się osobiście ${ }^{22}$. Włoski eksbiskup uprawiał intensywną religijną dyplomację i utrzymywał kontakty z wieloma możnymi patronami reformacji oraz jej działaczami, w tym celu podróżował kilkakrotnie do Prus i Polski w latach 1556-1560, aby spotkać się z księciem Albrechtem, wielkopolskimi magnatami wspierającymi luteranizm, a także z przywódcą ewangelików małopolskich Janem Łaskim. Jednym z wydawniczych efektów jego działań - poza wspomnianymi już wydaniami katechizmu - były także sygnowane jego nazwiskiem proreformacyjne druki polemiczne wychodzące w Królewcu po łacinie i w przekładach, m.in. wspierające Mikołaja Radziwiłła „Czarnego" (1515-1565) w jego kampanii wymierzonej w nuncjusza papieskiego Alojzego Lippomana ${ }^{23}$.

Poza przekładem Trepka spisał sygnowane posłowie (Do tego, kto będzie czedt, k. $\mathrm{C}_{6}$ rec.-C $\mathrm{C}_{7}$ rec.). On też zapewne nadał tytut, pod którym równolegle funkcjonuje tekst polski, informujący zarazem o zadedykowaniu dzieła młodemu Mikołajowi Radziwiłłowi (1549-1616), zwanemu później „Sierotką”, synowi Mikołaja „Czarnego”: Upominek, który Vergerius jasnemu panu Mikotajowi [--] postat24 (zob. il. 5).

Boże w perspektywie historycznej, czyli wstepne uwagi nad „Książami o tym, skąd wzięto początek Stowo Boże” Eustachego Trepki, w: Figura heretyka w nowożytnych sporach konfesyjnych, red. A. Bielak, W. Kordyzon, Warszawa 2017, s. 129-160;

22 W. Kordyzon, Rzymskie korzenie herezji, s. 106-107. O przekładzie Mleka duchownego w kontekście innych działań Trepki w tym czasie zob. ibidem, s. 109-110.

23 Mowa zwłaszcza o przedruku listu Lippomana do Radziwiłła wraz z odpowiedzią magnata będącą publiczną manifestacją wiary (uzupełnioną o komponenty przedstawiające sukcesy reformacji w regionie) wydanymi jako Duae epistolae altera Aloysii Lipomani Veneti [--] ad principem D. Nilcaum Radivilum [--], altera vero eiusdem [--] Radivili ad episcopum et legatum illum, Królewiec 1556 (VD 16: L 1981); zob. więcej M. Ptaszyński, Reformacja w Polsce a dziedzictwo Erazma z Rotterdamu, Warszawa 2018, s. 521-524. Rok później w Królewcu ukazał się przekład niemiecki (VD 16: L 1982), a polski trzy lata później już w innym ośrodku (Dwa listy na polski język wtaśnie wytożone, jeden Alojzego Lipomana Weneta [--] panu Mikotajowi Radziwitowi [--], a drugi tegoż to [--] pana [--] do tego biskupa, Brześć Litewski 1559). W roku wydania Mleka wyszły w Królewcu także inne dzieła Vergeria: Catalogus haereticorum (VD 16: K 175), De Gregorio papa eius nominis primo (VD 16: G 3130), Scholia in bina Pauli pape huius nominis quarto (VD 16: K 465), Formula fidei tradtia in synodo provinciali quae Lovitii in Polonia celebrata est (VD 16: 1874).

${ }^{24}$ Któremu było zadedykowane także łacińskie wydanie Daubmanna. 
Należy podkreślić dwuznaczność zawartą w polskim odpowiedniku łacińskiego munusculum, wyraz upominek oznaczał bowiem w XVI stuleciu tak 'podarek, prezent dany na pamiątkę' (co jest znaczeniem prymarnym i odpowiednikiem wyrazu łacińskiego ${ }^{25}$, jak i 'upomnienie, przestrogę' (co w polu semantycznym tego wyrazu lokuje również znaczenia związane z nauczaniem, dydaktyzmem) ${ }^{26}$. Kolejny tytuł Mlieko duchowne dla karmienia $i$ wychowania chrześsijańskich dziatek ku chwale boskiej - pojawia się dopiero na drugiej karcie ( $\mathrm{A}_{2} \mathrm{rec}$.) (zob. il. 6). Dla porównania łacińskie wydanie Morharta z 1554 r. zostało oznaczone tylko wyrazem Munusculum, natomiast w wydaniu Daubmanna oba alternatywne tytuły (Lac spirituale oraz Munusculum) zmieszczono na pojedynczej stronie tytułowej.

Przynależność gatunkową utworu można określać różnie ${ }^{27}$, jednak tłumacz polski w posłowiu wyraźnie informuje, że uznaje przekładany tekst za katechizm: „Nic w tym nie trzeba wątpić, iż ten katechizm będzie się tobie barzo krótki i niedostateczny widział" (k. $\mathrm{C}_{6}$ rec.). Tekst Valdésa-Vergeria, będący raczej zwięzłą renarracją wybranych wydarzeń biblijnych i ukazaniem ich znaczenia teologicznego, odbiega od najczęstszej formuły katechetycznej znanej w świecie luterańskim, czyli zainicjowanego przez Maty katechizm (1529) Marcina Lutra dialogu między uczniem i mistrzem ujętego w naprzemienne pytania i odpowiedzi. Jak zwróciła jednak uwagę Izabela Winiarska-Górska, we wczesnym okresie reformacji w języku polskim określenie „katechizm” miało charakter funkcjonalny, a niekoniecznie wskazywało na formę tekstu. Wyrazem tym określano w związku z tym nie tylko gatunek publikacji, ale i ogólniej sam jej przedmiot, czyli podstawowe prawdy wiary ${ }^{28}$.

25 Zob. J. Mączyński, Lexicon Latino-Polonicum ex optimis Latinae linguae scriptoribus concinnatum, Królewiec 1564, k. 238ver.: s.v. Munusculum.

$26 \mathrm{Na}$ co wskazują m.in. użycia z XVI w. zarejestrowane w tzw. słowniku warszawskim; zob. J. Karłowicz, A. Kryński, W. Niedźwiecki, Stownik języka polskiego, t. 7, Warszawa 1919, s.v. Upominek. Dla Lindego upominek 'upomnienie' wręcz jako znaczenie prymarne (przykłady użycia również na materiale z XVI w.); zob. S. B. Linde, Stownik języka polskiego, t. 6, Lwów 1860, s. 153: s.v. Upominać.

$27 \mathrm{Na}$ przykład R. A. Pierce (Pier Paolo Vergerio. The Propagandist, Roma 2003, s. 243) klasyfikuje włoskie wydania Valdésa jako „traktaty teologiczne” (wyodrębniając „katechizmy” jako osobną kategorię, do której nie zalicza Latte spirituale).

28 Zob. I. Winiarska-Górska, Staropolskie ewangelickie katechizmy i kancjonaty jako ksiażki formacyjne, w: Ewangelicyzm reformowany $w$ Pierwszej Rzeczypospolitej. Dialog z Europa $i$ wybory aksjologiczne $w$ świetle literatury $i$ piśmiennictwa XVI-XVII wieku, red. D. Chemperek, Warszawa 2015, s. 147-149. 
Te w dziele Valdésa-Vergeria zostały sfunkcjonalizowane w ramach nacechowanej prostotą i bezpośredniością opowieści o historii zbawienia. José Nieto sądził, że była to $\mathrm{w}$ istocie innowacyjna metoda katechizacji rozwijana samodzielnie przez Valdésa ${ }^{29}$. Pozwoliło to klarownie ustrukturyzować przedmiot nauczania, pokazując okres obowiązywania starotestamentowego Prawa („Zakonu” w tekście polskim), ujawniający ludzką grzeszność przez niemożność jego wypełniania, w kontraście do Ewangelii, która mówić miała o obietnicy zbawienia. Chronologicznie ułożone obrazy upadku Adama, ufności Noego, wiary Abrahama, Prawa danego Mojżeszowi i wreszcie Wcielenia stanowią podstawę narracji o usprawiedliwieniu tylko przez wiarę, co było wspólnym protestanckim postulatem, zarazem wywołującym niezgodę teologów rzymskich. Należy przy tym zauważyć, że Mleko duchowne w żadnej z szesnastowiecznych wersji językowych nie funkcjonowało oficjalnie jako utwór Valdésa, a więc kojarzono go zapewne z pierwszym redaktorem tekstu, czyli Vergeriem. Jednocześnie tekst Valdésa-Vergeria, tak ze względu na cechującą go prostotę, jak i dominację aspektu narracyjnego, bliskość tekstowi Pisma, nie miał wymiaru specyficznego konfesyjnie w ramach różnych nurtów reformacji. Z powodzeniem wydawany był w kręgach luterańskich (jak świadczą druki tybińskie i królewieckie), ale korzystano z niego także w pismach ewangelickich: jak zauważył E. Böhmer, w wydanym w 1545 r. włoskim przekładzie katechizmu Jana Kalwina anonimowy tłumacz wcielił - bez oznaczania tego faktu - całe partie utworu Valdésa do przedmowy autorstwa genewskiego teologa ${ }^{30}$.

Odbiorcami katechetycznego Mleka duchownego są deklaratywnie przede wszystkim dzieci („dziatki”), wzmiankowane już w tytule. W przedmowie do „pobożnego czytelnika” podkreśla się, że nauka podstaw wiary wpajana od najmłodszych lat skutkować będzie prawdziwym „pobożeństwem” także w wieku dorosłym. Motto umieszczone

29 J. C. Nieto, op. cit., s. 263-269. Jak wskazuje badacz, podobnym podejściem do katechizacji u początku XVI w., które opierałoby nauczanie prawd wiary na dziejach zbawienia (jednak znacznie bardziej erudycyjnym), cechuje się jedynie katechizm luterańskiego teologa Georga Witzela (Catechismus Ecclesiae. Lere und Handelungen des heiligen Christentums, Leipzig 1535 [VD 16: W 3875]), który w znacznej mierze bazuje na słabo znanym ówcześnie dziele Augustyna De catechizandis rudibus, podczas gdy pracę Valdésa cechuje znaczna niezależność od tego tekstu i oryginalność.

30 Zob. J. de Valdés, Instrucion cristiana, s. XII-XIII; J. C. Nieto, op. cit., s. 255-256 . 
na stronie tytułowej, pochodzące z Drugiego Listu do Tymoteusza, podkreśla ponadto, że osoba znająca Pismo Święte „od dziecinnych lat" przygotowuje się lepiej do zbawienia ${ }^{31}$. Zakres wieku odbiorców w tłumaczeniu polskim potraktowany został raczej szeroko i możliwie ogólnie: w przedmowie określa się ich także jako „młódź”, a zatem wyrazem zazwyczaj oznaczającym po prostu osoby młode ${ }^{32}$. Pewne wyobrażenie o docelowym odbiorcy dawać może także uwzględnienie adresatów dedykacji wydań królewieckich i tybińskiego, obaj byli bowiem dziećmi: młody Radziwiłł miał około siedmiu lat w momencie wydania przekładu polskiego, a Eberhard, syn księcia Wirtembergii - dziewięć, gdy Morhart drukował pierwsze wydanie łacińskie. Mleko duchowne nie było jednak zapewne skierowane bezpośrednio do młodych odbiorców, a zapoznanie się z przekazywanymi treściami mogło być zapośredniczone przez osoby wychowujące dzieci, na co wskazuje osobno wydzielony zwrot „ku chrześcijańskim rodzicom" wieńczący utwór. Nie zawiera on szczegółowych instrukcji, jak książkę wykorzystywać, ale przekazuje napomnienie o odpowiedzialności rodziny za chrześcijańskie wychowanie potomstwa „ku chwale boskiej”, a także wskazuje lakonicznie najważniejsze zagadnienia, których zrozumienie przynosi katechizm: woli Bożej („przeźrzenie”), Wieczerzy Pańskiej oraz istoty Trójcy Świętej.

Należy przy tym odnotować, że tytułowa metafora ujmująca podstawowe prawdy wiary jako „duchowe mleko” w swoim źródłowym kontekście, tj. Pierwszym Liście do Koryntian Pawła z Tarsu, odnosiła się nie tyle do dzieci, ile wszystkich znajdujących się u początku drogi duchowej w chrześcijaństwie, „niemowląt w Chrystusie”33. Figura ta, wykorzystywana $\mathrm{w}$ homiletyce, zwłaszcza patrystycznej, podkreślać

31 Por.: „Ty natomiast trwaj w tym, czego się nauczyłeś i co ci powierzono, bo wiesz, od kogo się nauczyłeś. Od lat bowiem niemowlęcych znasz Pisma święte, które mogą cię nauczyć mądrości wiodącej ku zbawieniu przez wiarę w Chrystusie Jezusie" (2 Tm 3, 14-15, przekład Biblii Tysiąclecia).

32 Choć występującym także w szeregach synonimicznych z wyrazem 'dziatki'; zob. Stownik polszczyzny XVI wieku, t. 14, Wrocław 1982, s.v. Mtodź.

33 Por.: „A ja nie mogłem, bracia, przemawiać do was jako do ludzi duchowych, lecz jako do cielesnych, jak do niemowląt w Chrystusie. Mleko wam dałem, a nie pokarm stały, boście byli niemocni; zresztą i nadal nie jesteście mocni. Ciągle przecież jeszcze jesteście cieleśni. Jeżeli bowiem jest między wami zawiść i niezgoda, to czyż nie jesteście cieleśni i nie postępujecie tylko po ludzku?” (1 Kor 3,1-3). Dla kontekstu egzegetycznego tych wersetów i dalszej bibliografii zob. K. H. Jobes, „Got Milk?”. A Petrine Metaphor in 1 Peter 2.1-3 Revisited, „Leaven”, 20, 2012, 3, s. 1-6. 
miała walory słowa Bożego jako odżywczego pokarmu dla ducha. Trepka w posłowiu, bazując być może na szerokim znaczeniu pierwotnym, podkreślił dwukrotnie, że utwór skierowany jest nie tylko do najmłodszych, ale także dorosłych oraz „letnich” (k. $\mathrm{C}_{7}$ ver.), czyli osób w podeszłym wieku. To o tyle istotne, że zapewnieniem tym starał się być może poszerzyć krąg odbiorców dzieła ze względu na niewystarczającą wciąż do celów katechetycznych produkcję drukarską protestanckich książek religijnych w języku polskim.

Warto w związku z tym zarysować, jakie jest miejsce Mleka duchownego w perspektywie innych polskojęzycznych druków katechetycznych tłoczonych ówcześnie w Królewcu. Wszystkie były elementem szerszej proreformacyjnej akcji agitacyjnej mającej na celu tak pozyskanie nowych zwolenników tego nurtu religijnego poza Księstwem, jak i zapewnienie polskojęzycznym poddanym pruskim właściwej literatury formacyjnej i edukacyjnej ${ }^{34}$. Zapotrzebowanie na katechizmy w językach wernakularnych wciąż rosło i obejmowało również osoby niepiśmienne. Sposób ich użytkowania precyzuje się np. w Kirchenordnung z 1558 r., gdzie wprost wyrażano nakaz, by nauczano lud katechizmu z wersji drukowanej, dbając przy tym o to, żeby katechizacja była zrozumiała dla miejscowej ludności, posługującej się językami innymi niż niemiecki (czyli dla użytkowników polskiego, litewskiego i staropruskiego) ${ }^{35}$. W 1556 r., gdy Aujezdecki tłoczył Mleko duchowne, nie istniał jeszcze, dość wierny zreszta, polski przekład Matego katechizmu Lutra dokonany przez Jana Radomskiego, który został wydany dopiero w $1562 \mathrm{r} .{ }^{36}$ Nie wiadomo także, czy wciąż funkcjonowało nieznane dziś z żadnego egzemplarza tłumaczenie Enchiridionu przygotowane przez Liboriusa Schadilkę i wydane ok. 1533 r., być może w oficynie Hansa Weinreicha ${ }^{37}$.

34 Dla ogólnego przeglądu charakteru i celów drukarstwa polskojęzycznego w Prusach tego czasu zob. J. Małłek, Ekspansja kultury polskiej na Prusy Ksiażęce XVI w., w: idem, Reformacja i protestantyzm $w$ Polsce i Prusach (XVI-XX w.), Toruń 2012, s. 295-306; zob. też Królewiec, w: Drukarze dawnej Polski od XV do XVIII wieku, t. 4: Pomorze, oprac. A. Kawecka-Gryczowa, K. Korotajowa, Wrocław 1962, s. 217-220.

35 W. Hubatsch, Geschichte der evangelischen Kirche Ostpreussens, Bd. 3: Dokumente, Göttingen 1968, s. 100.

36 M. Luther, Enchiridion. Catechismus maty prze plebany $i$ kaznodzieje niedouczone $i$ lud prosty, tł. J. Radomski, Królewiec 1562 (VD 16: L 5343).

37 Zob. V. Bock, op. cit., s. 144; zob. też J. M. Reu, Quellen zur Geschichte des Katechismus-Unterrichts, Bd. I/3,1a, Güttersloh 1927, s. 45-49. 
Zapewne istniały w obiegu katechizmy Jana Seklucjana z lat 1545, 1547 i $1549^{38}$ oraz Jana Maleckiego z 1546 r. ${ }^{39}$ Sądzi się, że także Aujezdecki mógł wydać w 1552 r. jakąś formę tłumaczenia Matego katechizmu, ale zachowane fragmenty druku nie pozwalają z całą pewnością potwierdzić tej hipotezy ${ }^{40}$. W 1556 r. ukazał się także w oficynie Hansa Daubmanna polski przekład katechizmu Johanna Brenza ${ }^{41}$, również opracowany przez Trepkę. Liczący ponad 300 kart wykład wiary, w podtytule opisany jako taki, „który możesz dobrze małą Bibliją nazwać”, znacznie przekraczał jako całość możliwości intelektualne przeciętnego wiernego. $Z$ tej perspektywy warto zwrócić uwagę na kompleksowość działań Trepki, który jednocześnie w innej oficynie zapewnił wydanie Mleka duchownego, przynoszącego treści znacznie prostsze, zwięzłe i rudymentarne.

Komunikatywność tekstu przekazywanego drukiem kształtowana była także środkami typograficznymi. Porównanie wydań utworu z oficyn Morharta, Daubmanna i Aujezdeckiego ukazuje w tym zakresie ciekawe zmiany, choć ze względu na skomplikowany proces wytwórstwa dawnej książki trudno jednoznacznie wskazać osoby (drukarz, wydawca-redaktor, tłumacz?) odpowiedzialne za te modyfikacje. W wydaniach Mleka duchownego, utworu będącego tekstem ciągłym (w przeciwieństwie np. do dialogowanego Enchiridionu Lutra), poza zastosowaniem stosunkowo prostej składni, pozbawionej długich okresów retorycznych, widoczna jest także chęć wyklarowania treści za pomocą typograficznej delimitacji. Poszczególne partie tekstu zostały we wszystkich wydaniach podzielone na krótkie bloki akapitowe, jednak utwór w różnych wydaniach zaopatrywany

38 J. Seklucjan, Simplex textus catechismi. Katechizmu tekst prosty dla prostego ludu, Królewiec 1545 (VD 16: L 5342); idem, Catechismus, to jest Nauka naprzedniejsza i potrzebniejsza ku zbawieniu o wierze krześcijańskiej, Królewiec 1547 (brak w VD 16); idem, Catechismus, to jest Krótka, prosta starej wiary chrześcijańskiej nauka, Królewiec 1549 (VD 16: S 5406); zob. też V. Bock, op. cit., s. 146-147; S. Rospond, Studia nad jezzykiem polskim XVI wieku (Jan Seklucjan, Stanistaw Murzynowski, Jan Sandecki-Malecki, Grzegorz Orszak), Wrocław 1949, s. 27-32.

39 J. Malecki, Catechismus, to jest Nauka krześcijańska od apostołów dla prostych ludzi we trzech czastkach zamkniona, Królewiec 1546 (VD 16: M 385); zob. też V. Bock, op. cit., s. 147.

40 Zob. Augezdecki Aleksander, w: Drukarze dawnej Polski, t. 4, s. 23; V. Bock, op. cit., s. 152.

41 J. Brenz, Catechismus to jest Zupetna nauk chrześcijańska [--] który możesz dobrze mata Biblija nazwać, tł. O. Trepka, Królewiec 1556 (VD 16: B 7666). 
Proprium autem per chriftianam regenerdtioneti.

AGNOSCA N T V Chriftum. Dominumilluint: qui nos à peccato, morte, $\sigma$ inferno redemit ac libes ranit.

DE V M quog; effe inuifibilem, incomprebenfis bilem o immortale, in quo fit (imò quiipfe fit)omnis potentid, sapientid, iuftitia, bonitas, mifericordia, wes ritas $\odot$ fidelitas.

QV I Deus omnipotens per uerbum funm credu sit Colum er terram, er quicquid in eis continetur. EODEM uerbo creature omnes in propria ef= fentia conferuantur er uegetantur, quas fic regit os gubernat, ut nefolium quidem fine ipfius uoluntate exarbore dilabatur.

COGNOSC A NT etiam Deum, creatis rebus omnibus bominem creaffe, fuperiorem 0 excellens tiorem cunctis que funt fuper terram, ut pote immortalem, fapientem, iuftum, ueracem $\sigma$ fidelem, quem deinde tot tantisóg dotibus ornatum in terreftri pas redifocollocauit.

is porró, amiffa per inobedientiam Dei imagine - fimilitudine, fimilis factus eft animantibus brutis, paßsbilitate er mortalitate, $\beta$ irrtibus ánimo immun= dis, iniuftitsa, impietate; malitia, or nequitia, Sicóg. inmutatus i paradifo terreftrieiectus.

C $v$ \& v s hominis fic lapf f pofteritas amnis, in exia liomalcens Adeprogenitori per omnid fimilis nat feitursex cuius inobedientia intelligant omnes opors tet Deum ipfis inimicŭ qui cos ueluti boftiliter etiam tractet, dumin cos fententiam aduer fus primum bos minem latam exercet.

INT E L LIG AN T quoq Deum ab ipfis inbes fem reputari, quatenus ex uniuey is animalibus, bo mo folus diuine uoluntati reluctatur.

GLISCENT E uerò bominum malitis, mifjo iluuio, extinxit Deushomines or iumenta, feriatis tantum Noab ,uxore, filijs, eorum \$ٔ uxoribus, cum magnobrutorum animantium numero. Quenöideo feruata funt, quòd Arca par fuerit ad ea feruadda, fed quonidm Noab credës Deum poffe or uelle promiffe. preftare, fidem eims uerbo babensin Arcamingref: fus est. ltás; non feruatus eft per A rcami fed per fidé; qua fulteus fe ip funs cum domefticis or brutis animalio bus Arce commifit.

POST dilmuium elegit Deus Abrabamumex om: nibus bomimbus, quem cum multis modis tentauifet

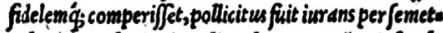
ipfuminerus femine beriedicendas omnes gëresipfums" fore mundiberedem, his promißis cum Abrabam credidiffet fides imputata efi illi ad iuftitiam.

C AB T E R V M abrabam pofteri,qui in mumes vofum populum accreucrant, guem etiam Dews fibi

A 3

Il. 1. [J. Valdés, P. P. Vergerio], Illustri atque optimae spei puero Eberhardo, illustrissimi principis et domini, domini Christophori Ducis Wirtembergensis etc., filio primogenito, munusculum Vergerii exulis Iesu Christi, [Tübingen] 1554, k. A A $_{2}$ ver.-A rec.; Österreichische Nationalbibliothek w Wiedniu, sygn. 79.Ee.156 ALT PRUNK

był $\mathrm{w}$ odmiennie kształtujące przekaz elementy paratekstowe, pełniące różne funkcje ${ }^{42}$.

Pierwsze kontrolowane przez Vergeria wydanie łacińskie z Tybingi z 1554 r. nie wykorzystuje dodatkowych paratekstów w prezentacji głównego wywodu. Delimitacja poszczególnych cząstek podkreślona została jednak poprzez użycie kapitalizowanych pierwszych słów każdego akapitu (zob. il. 1). Podział na akapity został przejęty przez

42 Termin ten, wywodzący się z koncepcji Gérarda Genette’a, oznacza ogół elementów tekstowych niebędących właściwą częścią utworu, które występują w danej materializacji dzieła, np. tytuł, dedykacja, posłowie, przypis, marginalium itp. O jego zastosowaniu do wczesnonowożytnej książki drukowanej zob. Renaissance Paratexts, ed. by H. Smith, L. Wilson, Cambridge 2011; I. Winiarska-Górska, Zwieńczenie formalne, uktad tekstu, deklaracja "auctoritas”, skróty biblijne, w: eadem, Szesnastowieczne przektady Pisma Świętego na język polski (1551-1599) jako gatunek nowożytnej ksiązki formacyjnej, Warszawa 2017, s. 129-168. 
ducatur, Magai ctenim refert, qua prima rus dimenta tenera at as imbibat, in quibus auñ omme tranfigat. Nam fi bonis a fueuerit, $a b$ his adulta non recedet, in malis, peiora indies proferet. Rur/um admonitos uelim pueros, qua bic collegimus eiufmodie f]e, qua fi probe intelligantur es objeruentur, in prelentie futuro feculo falutem adferant, fin ignorentur akt ne gligantur, in utraq; nita exitikm.

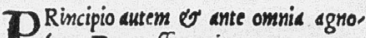
1 fcant Deume efe omnium parentem, per bumanam generationem, propitium autem $\checkmark$ placatum, per Chriftianam regenerationem.

Agnofeant bunc Deumeffeaternum $\mathrm{Pa}$ trem Domimi noftri lef $/ v$ Chrifit, of Fllum costernum, qui fatuto tempore ad redimen, doshomines, humanam naturam adfump fit, er Spiritum Sanctum, qui a Patre er Filio procedit.

Hunc uerum Deume efe inuifibilew, in comprehenfibilem \& immortalem, in quo fit emnipotentic, fapientia, bonitas, mifericor- dia, ueritas, \& fidelitas, imó fit ip a fapientia, bonitus, Erc.

Qui Deus Omnipotens per Verbum fu - Creatiod

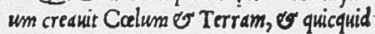
in eis continetur.

Eodem Verbo creatura omes in propria confortistio. ef fentid conferuantur \& uegetantur, quas fic regit ac gubernat, ut ne folium quidem, fine ipjius uoluntate ex arbore decidat.

No.cant etiand Deum, creatis rebus omni Image Dd. bus, hominem creauiffe fuperiorem, $\sigma^{\sigma}$ excel lentiorem cunctis qua funt fuper terram, nem pe ad ims ginem of fimilitudimem fram, qua tenus immortalis, apiens, instus, uer $a x, \mathcal{G}$ fi, delis erat, quem tot tantisq; dotibus ornatum, in terrestri Paradifo collocauit.

Qui homo amiffa per inobedientiam Dei Laffus Alas? imagime of fimilitudime, ¿'Paradifo eiectu, fi milis factus ef animantibus brutis, pa fibilitas te et mortalitate, Spiritibus autem immundis,

A iij iniw

Il. 2. [J. Valdés, P. P. Vergerio], Lac spirituale pro alendis ac educandis Christianorum pueris ad gloriam Dei. Munusculum Vergerii [--] Domino Nicolao, [--] principis D. Nicolai Radivili [--] primogenito. Adiecta sunt: Prima christianae religionis elementa [--] per Andream Tricesium [--] et Mathiam Stoium, Königsberg [1554-1556?], k. A2ver.-A rec.; Herzog August Bibliothek w Wolfenbüttel, sygn. A: 1228 Theol. (1)

Daubmanna za pierwszym wydaniem Morharta. W druku królewieckim innowacją są natomiast elementy paratekstowe w postaci marginaliów znajdujących się na zewnętrznych krawędziach każdej karty (zob. il. 2). Występują w większości wydzielonych akapitów, pełniąc funkcję delimitacyjną, a także indeksacyjną, ponieważ podsumowują treść poszczególnych paragrafów.

Co istotne, marginalia w takim samym kształcie przejęto w wydaniu Aujezdeckiego z 1556 r. (zob. il. 3). Sądzić można, że wraz ze zmianą języka na wernakularny wzrosło także ich znaczenie, zwłaszcza gdy weźmie się pod uwagę fakt, że polszczyzna w rejestrze literackim była wciąż kształtowana, a konwencje jej użycia podlegały dynamicznym zmianom w stosunkowo nowym medium, jakim był druk. Umieszczenie marginaliów w tekście dydaktycznym nie tylko usprawniało przeszukiwanie i indeksację treści zawartych w książce materialnym obiekcie - lecz mogło mieć także konsekwencje językowe, stabilizowało bowiem wernakularną terminologię religijną, 


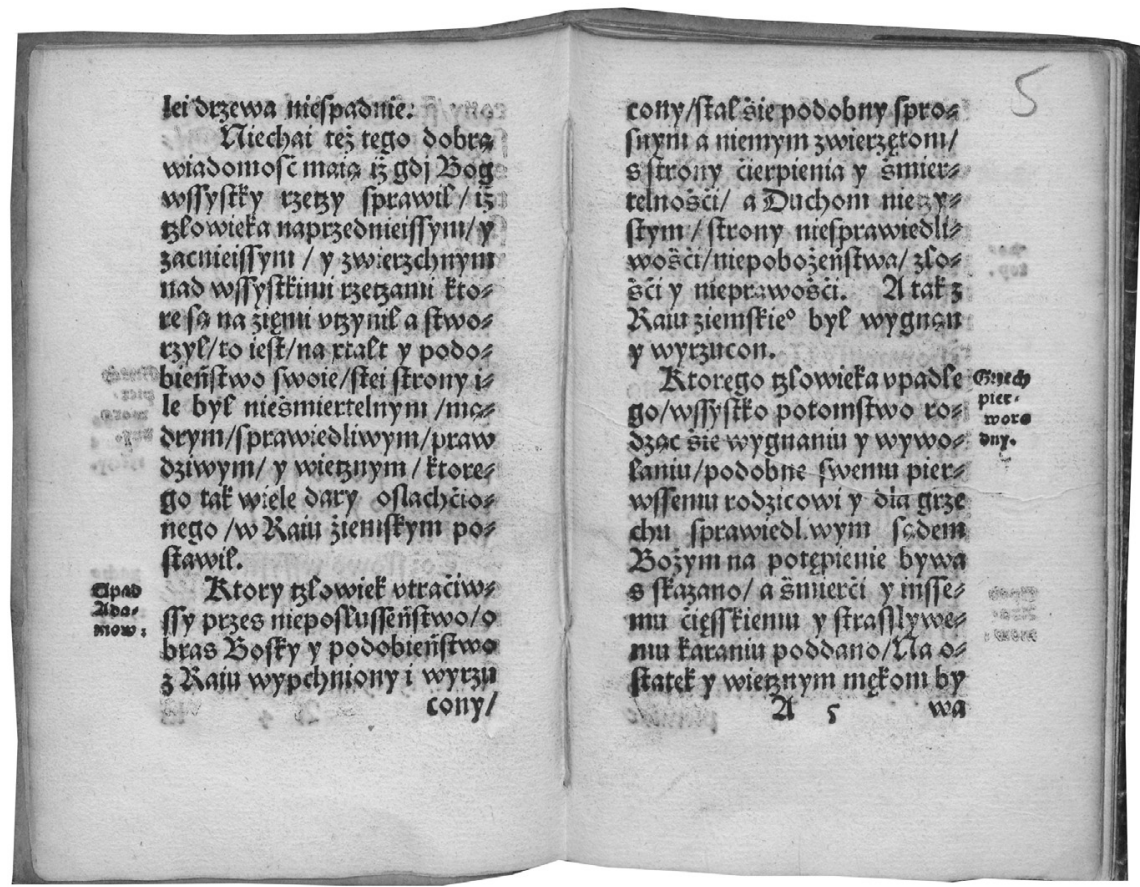

Il. 3. [J. Valdés, P. P. Vergerio], Upominek, który Vergerius jasnemu panu Mikotajowi [--] postat - Mlieko duchowne dla karmienia i wychowania chrześcijańskich dziatek ku chwale Boskiej, tł. O. Trepka, Królewiec 1556, k. A 4 ver.-A 5 rec.; Geheimes Staatsarchiv Preussischer Kulturbesitz w Berlinie, sygn. 60,20

upowszechniając umieszczone na marginesach frazy w edukacji poziomu podstawowego. To, że taka decyzja typograficzna miała znaczenie funkcjonalne, pomoże unaocznić porównanie przekładu polskiego z wydaniem tłumaczenia niemieckiego z 1555 r., w którym również pojawiają się marginalia (zob. il. 4). Nie służą one jednak organizacji wewnętrznej tekstu, ale stanowią odsyłacze do źródła zewnętrznego w stosunku do katechizmu, czyli Biblii. Sugerują zatem czytelnikowi praktykę intertekstualnej lektury katechizmu z Pismem w ręku. Dla czytelnika słabiej wykształconego duża liczba odniesień pozatekstowych może oczywiście pełnić funkcję autorytatywną i przekonywać o prawomocności twierdzeń teologicznych, nawet gdy nigdy nie dojdzie do ich weryfikacji w toku lektury. Niemniej budowanie powiązań z Biblią w marginaliach tekstu Valdésa-Vergeria w wydaniu niemieckim zakłada przynajmniej jakąś część odbiorców zdolnych do ich zrekonstruowania, podczas 
pral, 104 . Das aud ebent butech Dafele Sap. 6.12, big wott/alle Creatutent bns bes Enat. $6+20$. [abopff/in irem aignen weren bes Xuc. 12. watet vno exbalten werben/ wol,

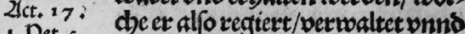
4. pet.s. leitet/Das obne fein millen auch nid) cin blat pom baum fellet.

Sie follen auch wiffent / bas

Gen, 1. Bott/nach demersuruozalle oing जap. 2. er/chaffen/audben CDen/chê ges 1. Cor. 16 . matht babe/ ood bóbet vito firtz

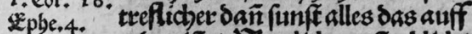
etsenifit / Temlich onfterblich/ weif/geted)t/watubafftig/teslich pustrew / pno nad dem ex ibne mit difen fout ons boben Baben

Gen.2. gesterct / babe ct in íbet follichs auch in oas Jedifhe paradeif gefert.

Gen.3.6.8 Det felbigmenf(h) als ct: butech) Bier. 17 . pngeborfam Das 2 bils Gottes 3oan. 3. ( tad) Sem ex exfchaffen) fatent

3. Cor.2. laffen / ons safflb verlozen bat/ उffer Senvnuetniinffigen Ties

ret: eet glet(h) twozben/an brtgenthach/ letoen vns ferben / im berten as bet ben vnteinen Geifetn'/ mit vngterechtigteit / bofbeit vuns (chaletbeit/2ud) alfo verendett (bert.32 vno verwandelt auf Sem Jedi= folen Paradeif geffofen wozs sct.

Difes ungtebosfantert vns von $\mathrm{Pr} .14 .528$ Gott abgefallnen ODenictien 3ob.14.15 Trachtommen alle fampt / bie 2. Cor. 150 jetsund in ellendt geborn / mers kom. 3 . beti jem exfen Datter $20 \mathrm{am}$ ourchan gletch) geseliget bito $\mathrm{et}=$ botn : Saber Dann außj dífem vn= geborfan alle menidben verffent vinto lcbanen miffen / Sas Gott secl. $x_{2}$. Ibnen feinot fei i auch mit kiont.5. ibnent als mit feinden bandle/ Jit bem bas et aud an jinet ben Eententy onno Ditbetl / Oas cint mal wiber ben exfen (PQnfeben gefelt iff/ubet viso volffectet.

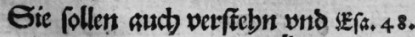
mecten/

Il. 4. [J. Valdés, P. P. Vergerio], Ein edel schriftlich Kleinath und Verehrung, tł. B. Hagen, Tübingen 1555, k. A 5 ver.-A 6 rec.; Bayreische Staatsbibliothek w Monachium, sygn. Catech. 45 Beibd. 3

gdy w polskim wydaniu Aujezdeckiego przeciwnie, Mleko duchowne jawi się jako tekst autonomiczny, mający służyć rudymentarnej edukacji religijnej.

Zasady wydania

Podstawę wydania stanowi druk z 1556 r. z królewieckiej oficyny Aleksandra Aujezdeckiego ( $8^{\circ}$, s. nlb. 24, k. A-C $\mathrm{C}_{8}$, karty $\mathrm{A}_{1}$ ver., $\mathrm{C}_{3}$ ver., $\mathrm{C}_{5}$ ver., $\mathrm{C}_{8}$ rec.-ver. niezadrukowane) opisanego na stronie tytułowej (zob. il. 5) jako: Vpominek. | ktory Vergerius Ja=| snemu panu / Mikotaiowi. $O=\mid$ swieconego Pana: Mikotaia Radźiwital Kxiażećia w Olice y Wnieświeżu Woiewody Wi | leńskiego e[t]c. Synowi | pierwssemu |postat. Drugi tytuł znajduje się na k. A rec. (zob. il. 6): Mlieko Du | chowne. Dla karmie | nia y wychowania Chrześs | ciańskych Dziatek/ ku | chwale boskiei. Informacje o wydawcy znajdują się w kolofonie na k. $\mathrm{C}_{7}$ ver.: Wycisnąt / Alexan $=\mid$ der Augezdecky/ $w \mid$ Krolewcu Pru=| skym. Roku | pańskiego. | 1556. 
Przygotowując niniejsze wydanie, korzystałem z jedynego znanego obecnie egzemplarza przechowywanego w Geheimes Staatsarchiv Preußischer Kulturbesitz w Berlinie i skatalogowanego pod sygnaturą 60,20. Wolumen pochodzi z księgozbioru Staats- und Universitätsbibliothek Königsberg, gdzie funkcjonował pod historyczną sygnaturą Ce 1071.

Sporządzając transkrypcję, zmodernizowano interpunkcję, pisownię łączną i rozdzielną oraz ortografię małych i wielkich liter. Wielkimi literami zapisywano zaimki i przymiotniki odnoszące się do osobowego Boga chrześcijańskiego (np. z Nim itp.) oraz przeciwstawianą w tekście parę wyrazową Zakon ('Prawo') i Ewanjelija. Według podstawy zachowano podział na akapity oraz lokalizację marginaliów, wprowadzając jedynie dodatkowy podział pomiędzy przedmową Pobożnemu Czytelnikowi a główną częścią tekstu.

Skróty rozwiązano w nawiasach kwadratowych, np. S. $\rightarrow$ $S[$ więty]. Nie oznaczano rozwinięć abrewiacji spółgłosek nosowych, np. Ewāgelia $\rightarrow$ Ewangelija, oraz końcówek fleksyjnych przypadków zależnych, np. ziemskie $\rightarrow$ ziemskiego. Nie oznaczano także uzupełnień przyimków zgodnych z nagłosem związanych z nimi wyrazów, dodawanych w miejscach wymaganych przez współczesne zasady, np. wygnaniu $\rightarrow w$ wygnaniu, ftrony $\rightarrow z$ strony.

Pozostałości grafii łacińskiej zostały usunięte, np. wneth $\rightarrow$ wnet, $x$ tatt $\rightarrow$ kstatt, vpadaia $\rightarrow$ upadaja, Ostaphii $\rightarrow$ Ostafi, catechism $\rightarrow$ katechizm. Obcojęzyczne nazwy własne pozostawiono jednak bez zmian, np. Vergerius, (góra) Syna.

Nie wyrównano obocznie występujących form, bez względu na frekwencję i genezę, w wyrazach: abo \| albo, krotofile \| krotochwile, Abram \| Abraham.

Ze względu na brak konsekwencji w podstawie samogłoski nosowe zapisano według normy współczesnej, np. szczeście $\rightarrow$ szczęście. Usunięto także przypadki unosowień wtórnych przed spółgłoskami nosowymi, np. znąna $\rightarrow$ znana.

Pisownię głosek $i, j, y$ wyrównano do zasad współczesnych (np. nieprziiaciele $\rightarrow$ nieprzyjaciele, nieprawośćy $\rightarrow$ nieprawości, pożiteczne $\rightarrow$ pożyteczne, staranijm $\rightarrow$ staranim, więceij $\rightarrow$ więcej, wpojta $\rightarrow$ wpoita). Pozostawiono archaiczne formy bez joty w wyrazach Ociec i przyść (równolegle do przyjdzie) oraz w formach stopnia najwyższego przymiotników i przysłówków (np. nawięcej, nawinniejszym). W wyrazach pochodzenia obcego zastosowano rozszerzoną pisownię do -ij-, -yj-(np. chrześciański $\rightarrow$ chrześcijański, Mariej $\rightarrow$ Maryjej). 
Zastosowano także pisownię grup -gi-, -ge- z jotą w wyrazach egipskiej $\rightarrow$ eipskiej, Ewangelija $\rightarrow$ Ewanjelija.

Zachowano pisownię świadczącą o ścieśnionej wymowie $e$ w wyrazie potym, w końcówkach narzędnika (np. staranim) oraz w wygłosie rzeczowników i zaimków liczby mnogiej, np. ty ('te'), rodzicy ('rodzice'), rozkoszy ('rozkosze'). Zapis ścieśnionego o oddawano natomiast według normy dzisiejszej, np. ktory $\rightarrow$ który, Bog $\rightarrow$ Bóg, także w historycznych formach przymiotników rzeczownikowych, np. Adamow $\rightarrow$ Adamów.

Głoski dźwięczne i bezdźwięczne zapisano według dzisiejszych zasad, np. prętko $\rightarrow$ prędko, nadchnionei $\rightarrow$ natchnionej, Moifelf $\rightarrow$ Mojzesz, otrześwione $\rightarrow$ otrzeźwione, przes $\rightarrow$ przez, znalast $\rightarrow$ znalazt.

Miękkość i twardość głosek oznaczono według dzisiejszej normy, np. kaznią $\rightarrow$ kaźnią, się $\rightarrow$ się, mtodz $\rightarrow$ mtódź. Zachowano jednak archaiczne formy, które dzisiaj utraciły miękkość (np. przywiedzieni, mliekiem) lub ją nabyły (np. bliżnego).

Znak $\int$ (długie $s$ ) oddano jako $s\left(\int t a c ́ \rightarrow s t a c\right)$, ś (oflachíionego $\rightarrow$ oślachcionego) lub $z$ (befkoraniu $\rightarrow$ bezkoraniu), dwuznaki $\int s$, sf i $\iint$ jako sz (miefskać $\rightarrow$ mieszkać, święth $\int e \rightarrow$ świętsze), $\dot{z}($ ćieffkiemu $\rightarrow$ cieżkiemu), $\dot{z} s z$ (np. nawy $\int e \rightarrow$ nawyższe) lub zs (sfkąd $\rightarrow$ zskad), natomiast znak $\ddot{s}$ jako $s z(n a \ddot{s} \rightarrow$ nasz, chce $\ddot{s} \rightarrow$ chcesz). Zachowano archaiczne formy wyrazów snur ('sznur'), (xtatt $\rightarrow$ ) kstatt ('kształt') oraz (doświat $\iint y t \rightarrow$ ) doświadszyt. Stosowaną $\mathrm{w}$ podstawie ligaturę $t z$ transkrybowano jako dwuznak $c z$ (np. rzetzq $\rightarrow$ rzeczq).

Rozróżnienie spółgłosek $t$ i $l$ zachowano według podstawy jako zgodne z normą dzisiejszą. Za podstawą zachowano nazwę miejscową $w$ Olice (w Ołyce).

Zastosowano dzisiejszą pisownię spółgłosek podwojonych, np. krotoffle $\rightarrow$ krotofile, duffaniu $\rightarrow$ dufaniu, Radziwita $\rightarrow$ Radziwitta. Według podstawy równolegle zachowano zapisy wyrazu podano \| poddano.

Nie ingerowano w archaiczną grupę spółgłoskową w wyrazie przeźrzeniu. Nie korygowano historycznej formy barzo ('bardzo'). Pozostawiono także przymiotniki zachowujące pisownię bez uproszczeń grup spółgłoskowych, np. ludzskie, świetskiej. Nie modyfikowano zapisu świadczącego o wymowie frykatywnej w wyrazach czterzy ('cztery') i bierza ('biorą).

Bez modernizacji pozostawiono historyczne końcówki fleksyjne, np. dopełniacza (pracej ['pracy']), celownika (ludu ['ludowi'], żadze ['żądzy']), narzędnika (naszem ['naszym']), miejscownika (Synie 
['Synu'], Bodze ['Bogu'], patacoch ['pałacach']). Zachowano także historyczną formę czasownikową trzeciej osoby liczby pojedynczej doroście. Bez zmian pozostawiono archaiczne formy w rodzaju nijakim $\mathrm{w}$ imiesłowach biernych (np. jest zniesiono) oraz przymiotnikach (np. imię Pana Chrystusowo). Nie ingerowano również w dawną postać imiesłowu biernego uprzedniego (przysiagwszy).

Wykaz koniektur wprowadzonych do tekstu

* wich - poprawka wydawcy; wwych - podstawa (błąd).

** któ<r $>y$ - poprawka wydawcy; ktoiy - podstawa (błąd).

*** naprzednie<j>sze - poprawka wydawcy; naprzedniefJe - podstawa (błąd).

**** Ewanjeli<je>j - poprawka wydawcy; Ewanjelij - podstawa (błąd).

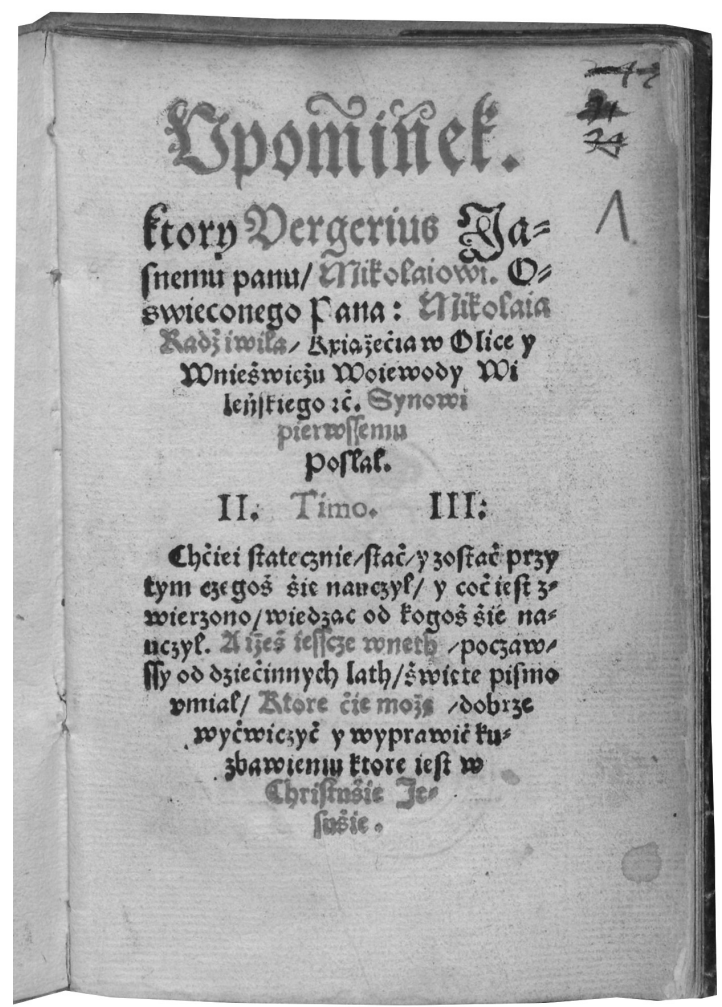

Il. 5. [J. Valdés, P. P. Vergerio], Upominek, który Vergerius jasnemu panu Mikotajowi [--] postat - Mlieko duchowne dla karmienia i wychowania chrześsijańskich dziatek ku chwale Boskiej, tł. O. Trepka, Królewiec 1556, strona tytułowa z dedykacją (k. A rec.); Geheimes Staatsarchiv Preussischer Kulturbesitz w Berlinie, sygn. 60,20 


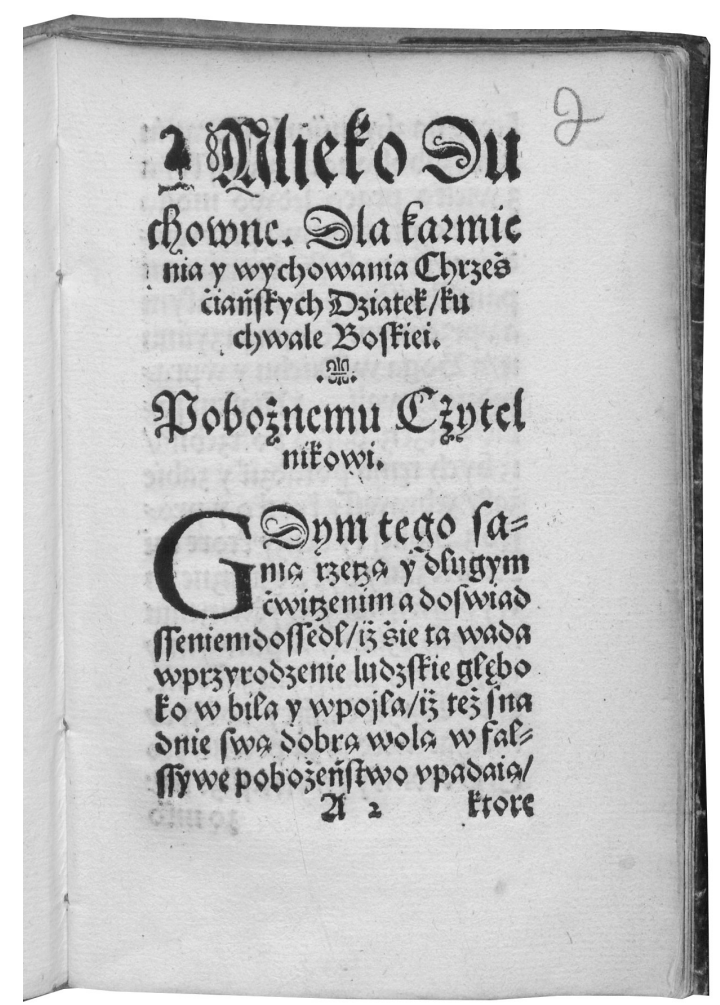

Il. 6. [J. Valdés, P. P. Vergerio], Upominek, który Vergerius jasnemu panu Mikotajowi [--] postat - Mlieko duchowne dla karmienia i wychowania chrześcijańskich dziatek ku chwale Boskiej, tł. O. Trepka, Królewiec 1556, drugi tytuł utworu i początek przedmowy (k. $A_{2}$ rec.); Geheimes Staatsarchiv Preußischer Kulturbesitz w Berlinie, sygn. 60,20

\section{Upominek,}

który Vergerius jasnemu Panu Mikołajowi ${ }^{1}$, oświeconego Pana Mikołaja Radziwiłła ${ }^{2}$, książęcia w Olice i w Nieświeżu, wojewody wileńskiego etc., synowi pierwszemu posłał

\section{$2 \operatorname{Tm} 3:$}

„Chciej statecznie stać i zostać przy tym, czegoś się nauczył i coć jest zwierzono ${ }^{3}$, wiedząc, od kogoś się nauczył. A iżeś jeszcze wnet, począwszy od dziecinnych lat, Swięte Pismo umiał, które cię może

1 Mikołajowi - Mikołajowi Radziwiłłowi (1549-1616), zwanemu „Sierotką”.

2 Mikotaja Radziwitta - Mikołaja Radziwiłła (1515-1565), zwanego „Czarnym”.

3 coć jest zwierzono - co zostało ci powierzone. 
dobrze wyćwiczyć i wyprawić ${ }^{4}$ ku zbawieniu, które jest w Chrystusie Jezusie" $"$

\section{Mlieko duchowne \\ dla karmienia i wychowania chrześcijańskich dziatek ku chwale boskiej}

\section{Pobożnemu Czytelnikowi}

Gdym tego samą rzeczą i długim ćwiczenim a doświadszeniem doszedł, iż się ta wada w przyrodzenie ludzskie głęboko wbiła i wpoiła, iż też snadnie ${ }^{6}$ swą dobrą wolą w fałszywe pobożeństwo upadają ${ }^{7}$, które na zbytnim bezkoraniu i na zabobonach zawisło ${ }^{8}$, a z wielką pracą ledwo mogą być do prawdziwej przywiedzieni, którą łaskę, którą nam pan Chrystus podawa, całym a uprzejmym sercem przyjmuje, a Boga w Duchu i w prawdzie chwali. Miałem sobie za rzecz barzo potrzebną, iżbych temu poradził i zabieżał, zebrawszy krótko i prosto z Biblijej ty rzeczy, które mi się widziały być pożyteczne ku wyprawieniu i wyćwiczeniu małych dziatek w prawym i w szczerym Pańskim zakonie ${ }^{9}$. A to chrześcijańscy rodzicy niechaj wiedzą za pewne, którzy potomki swoje jeszcze barzo młode będą chcieć w tej nauce dobrze wyćwiczyć i wyuczyć, iż za tym staranim do tego przyjdzie, iż fałszywe pobożeństwo będzie odrzucono, a prawdziwe przywrócono. Bo wiele na tym należy ${ }^{10}$, jakie ćwiczenie młódź z przodku ma mieć, a jakiej się nauki z młodu ma napić, w której by swój wszystek wiek przetrwała ${ }^{11}$.

Bo gdy się dobrej przyuczy i przyzwyczai, gdy doroście, od niej nie odstąpi. Jeśli złej, co dalej, tym więcej dzień podle dnia ${ }^{12}$ gorszą będzie pokazowała. Nadto napominam tu dziatek, iż ty rzeczy, którem tu zniósł i zebrał, takowe są, które, jeśli będą rozumiane i chowane,

4 wyprawić - udoskonalić, wyuczyć.

5 Por.: „Ty natomiast trwaj w tym, czego się nauczyłeś i co ci powierzono, bo wiesz, od kogo się nauczyłeś. Od lat bowiem niemowlęcych znasz Pisma święte, które mogą cię nauczyć mądrości wiodącej ku zbawieniu przez wiarę w Chrystusie Jezusie" (2 Tm 3, 14-15).

6 snadnie - łatwo.

7 pobożeństwo - pobożność.

8 na [--] bezkoraniu [--] zawisto - sens: wynika z niepowściągliwości.

$9 w[--]$ Pańskim zakonie - w słowie Bożym (Piśmie Swiętym).

10 na tym należy - od tego zależy.

11 swój wiek wszystek przetrwata - sens: przeżyła całe swoje życie.

12 dzień podle dnia - dzień po dniu. 
i tu, i na potym w przyszłym wieku ${ }^{13}$ zbawienie przyniosą. A jeśli ich kto nie będzie umiał i niedbale ich zaniecha, tego i tu, i na onym świecie o zatracenie przyprawią ${ }^{14}$.

A napierwej i nade wszystko niechaj Boga znają być wszystkich Ojcem przez ludzskie rodzenie ${ }^{15}$, a łaskawym i ubłaganym przez chrześcijańskie odnowienie abo znowu narodzenie ${ }^{16}$. Też niechaj to wiedzą i znają, iż ten Bóg jest wieczny Ociec Pana naszego Jezusa Chrysta; i Syn z Nim wespółek ${ }^{17}$ wieczny, który naznaczonego i pewnego czasu, iżby ludzi odkupił, człowiecze przyrodzenie na się wziąr ${ }^{18}$; też i Ducha Świętego, który od Ojca i od Syna pochodzi.

A iż ten Bóg jest niewidomy ${ }^{19}$, nieogarniony, nieśmiertelny, w którym jest wszechmocność, mądrość, dobroć, miłosierdzie, prawda i wierność, i owszem, iż jest prawą, szczerą mądrością i dobrocią.

Który Bóg wszechmogący przez słowo swoje stworzył niebo i ziemię, i cokolwiek jest na nich etc.

Toż słowo wszystki rzeczy w ich* własnej istności zachowawa ${ }^{20}$, otrzeźwia i ożywia, które tak rządzi i sprawuje, iż też ani list ${ }^{21}$ bez Jego wolej drzewa nie spadnie.

Niechaj też tego dobrą wiadomość mają ${ }^{22}$, iż gdy Bóg wszystki rzeczy sprawił, iż człowieka naprzedniejszym i zacniejszym, i zwierzchnim nad wszystkimi rzeczami, które są na ziemi, uczynił a stworzył, to jest na kstałt i podobieństwo swoje z tej strony ${ }^{23}$, ile był nieśmiertelnym, mądrym, sprawiedliwym, prawdziwym i wiecznym, którego tak wiele dary oślachcionego ${ }^{24} \mathrm{~W}$ raju ziemskim postawił.

Który człowiek, utraciwszy przez nieposłuszeństwo obraz boski i podobieństwo, z raju wypchniony i wyrzucony, stał się podobny

Stworzenie rzeczy

Zachowanie rzeczy

Upad Adamów

13 w przysztym wieku - sens: w przyszłości.

14 o zatracenie przyprawia - sens: spowodują potępienie.

15 przez ludzskie rodzenie - ze względu na stworzenie ludzkości.

16 chrześcijańskie odnowienie abo znowu narodzenie - mowa o Nowym Przymierzu, tj. odkupieniu grzechów ludzkości przez Chrystusa.

17 z Nim wespótek - wraz z Nim, tak jak On.

18 cztowiecze przyrodzenie na się wziąt - przyjął ludzką naturę. Mowa o wcieleniu Chrystusa.

19 niewidomy - niewidzialny.

20 w ich wtasnej istności zachowawa - zachowuje ich właściwości (istność - odpowiednik terminu łac. essentia).

21 list - liść.

22 tego dobra wiadomość mają - niech dobrze wiedzą o tym.

23 z tej strony - pod tym względem.

24 wiele dary oślachcionego - uhonorowanego wieloma darami. 
sprośnym a niemym ${ }^{25}$ zwierzętom z strony ${ }^{26}$ cierpienia i śmiertelności, a duchom nieczystym z strony niesprawiedliwości, niepobożeństwa, złości ${ }^{27}$ i nieprawości. A tak z raju ziemskiego był wygnan i wyrzucon. Grzech Którego człowieka upadłego wszystko potomstwo, rodząc się pierworodny $\mathrm{w}$ wygnaniu i wywołaniu ${ }^{28}$, podobne swemu pierwszemu rodzicowi ${ }^{29}$ i dla grzechu sprawiedliwym sądem Bożym na potępienie bywa zskazano, a śmierci i inszemu ciężkiemu i straszliwemu karaniu poddano, na ostatek i wiecznym mękom bywa podano, jeśli tu za żywota nie będzie do Boga nawrócenie i występków odpuszczenie.

Potop A gdy się tym więcej szerzyła i mnożyła złość ludzska, posławszy Bóg potop, zagubił ludzi i bydło, tylko zachowawszy Noego, żonę i syny, i ich żony, z pewną liczbą zwierząt niemych, które nie dlatego w całości zostały ${ }^{30}$, iżby arka Noego temu była sprostać mogła, ale iż Noe, wierząc, iż Bóg mógł obietnice ziścić, dawając wiarę słowu Jego, wszedł do arki abo do korabia, a tak był zachowan nie przez korab, ale przez wiarę, której się podpierając, w korab sam z swoimi i z zwierzęty wstąpił.

Abram Po potopie wybrał Bóg Abrahama ze wszystkich ludzi, którego gdy dziwnymi sposoby kusił, a wiernym znalazł i doświadszył ${ }^{31}$, obiecał mu był, sam przez się przysiągwszy ${ }^{32}$, iż w jego plemieniu miały dostać szczęścia wszystki narody, a iż miał być dziedzicem świata. Tym obietnicom gdy Abram uwierzył, była mu wiara przytćciona ku sprawiedliwości ${ }^{33}$.

Mojzesz A gdy Bóg wyswobodził z niewolej eipskiej potomki Abrahamowe, którzy się byli tak barzo rozmnożyli, iż ich był wielki poczet ludu, któ<r $>y^{* *}$ był sobie Bóg za osobny klenot obrał ${ }^{34}$, temuż Zakon na górze Syna ${ }^{35}$ przez Mojzesza podał ${ }^{36}$, przy którego obwieszczaniu wielkimi i dziwnymi cudami majestat się boski okazał.

\footnotetext{
sprośnym a niemym - bezrozumnym i nieposługującym się mową.

z strony - pod względem.

7 ztości - grzeszności.

8 wywotaniu - banicji, wygnaniu.

pierwszemu rodzicowi - Adamowi.

30 w catości zostaty - sens: zostały zachowane.

31 wiernym [--] doświadszyt - sens: upewnił się o jego wierności.

32 sam przez się przysiagwszy - sens: sam z siebie złożywszy obietnicę.

33 byta mu wiara przytćciona ku sprawiedliwości - sens: został obdarowany wiara w Bożą sprawiedliwość.

34 za osobny klenot obrat - sens: szczególnie sobie upodobał.

35 górze Syna - górze Synaj; por. łac. mons Syna.

36 temuż Zakon ... podat - potomkom Abrahama podał Prawo. Tu mowa o tablicach Dziesięciu Przykazań.
} 
Ten Zakon nawięcej jest dlatego dan i głosem boskim powtó- Zakon rzon, iżby ludzie stąd nieprawości i występki swoje, i wrodzoną złość przyrodzenia swego ${ }^{37}$ poznali. Abowiem gdy Zakon pod winą przeklętstwa $^{38}$ i śmierci wiecznej rozkazuje i mówi: „Miłuj Pana Boga twego z całej dusze twojej, z całego serca twego, ze wszystkich sił twoich, i bliżnego twego, jako samego siebie" ${ }^{39}$, ludzie swoje przyrodzenie i swoje sprawy ku temu snurowi sprawiedliwości boskiej naciągając ${ }^{40}$, snadnie obaczyć mogą, iż od takowego posłuszeństwa daleko się odstrzelilii" ${ }^{41}$ a iż jej swoją mocą i siłą nie mogą sprostać i wypełnić. Ta mdłość siły ${ }^{42}$ człowieczej dlatego ma być znana i na baczeniu miana, iżby się ludzie sprawiedliwego Sądu Bożego lękając, a na własną sprawiedliwość się nic nie sadząc ${ }^{43}$, ani w niej nadzieje pokładając, do jednacza ${ }^{44}$ Syna Bożego wiarą uciekali, a przez Jego sprawiedliwość i dosyć uczynienie byli zachowani i zbawieni. Temu Zakonowi, który nam grzech ukazuje i nas w nim przepiera ${ }^{45}$, i który się w Dziesiąci Mandaciech ${ }^{46}$ boskich zawiera, przydał Pan Bóg tamże insze prawa i zakony o ceremonijach abo o zwierzchniej Bożej pokłonie $^{47}$ i o wszystkich sprawach postanowienia świetskiej rzeczy pospolitej ${ }^{48}$, które dlatego nawięcej są dane i ustawione ${ }^{49}$, iżby im lud jako mistrzowi służył abo za nimi jako za przewodnikiem szedł aż do przyścia Pana Chrystusowego, a iżby się też przez nie od inszych

37 wrodzona ztość przyrodzenia swego - sens: ludzkiej natury naznaczonej piętnem grzechu pierworodnego.

38 pod wina przeklętstwa - pod karą potępienia.

39 Por.: „Będziesz miłował Pana, Boga twojego, z całego swego serca, z całej duszy swojej, ze wszystkich swych sił” (Pwt 6, 5) oraz „Nie będziesz szukał pomsty, nie będziesz żywił urazy do synów twego ludu, ale będziesz miłował bliźniego jak siebie samego" (Kpł 19, 18). W Nowym Testamencie (Mt 22, 37-40; Mk 12, 29-34; Łk 10, 26-29) sformułowane jako tzw. przykazanie miłości.

40 ku ... snurowi sprawiedliwości boskiej naciagając - przenośnie: porównując swoje postępowanie do zasad wyznaczonych przez Boga (snur - sznur).

41 od postuszeństwa ... się odstrzelili - sens: odbiegli od zasad postępowania.

42 mdtość sity - słabość.

43 na wtasna sprawiedliwość się nic nie sadząc - sens: nie oglądając się na ziemskie poczucie sprawiedliwości.

44 jednacza - orędownika, pośrednika.

45 nas $w$ nim przepiera - sens: poucza nas o grzechu.

46 w Dziesiaci Mandaciech - w Dziesięciu Przykazaniach.

47 o zwierzchniej Bożej poktonie - sens: o widocznych sposobach sprawowania kultu.

48 postanowienia świetskiej rzeczy pospolitej - ustanowienia władzy ziemskiej.

49 ustawione - ustanowione. 
poganów oddzielili i od nich różni byli. A to dlatego, iżby on lud, z którego się miał Mesyjasz narodzić, na świecie tym był zacniejszy i okazalszy.

A aczkolwiek przeciwko temu ludu żydowskiemu Bóg wielkie i prawie ${ }^{50}$ ojcowskie dobrodziejstwa pokazował, a wszakoż on im więtsze dobrodziejstwa brał, tym więtszym niepobożeństwem i niewdzięcznością to Bogu dobrodziejowi swemu oddawał.

Wcielenie Gdy przyszedł on czas od Boga naznaczony, Syn Boży, który tenże Syna Bożego jest wiecznym słowem Bożym, człowiecze ciało w żywocie ${ }^{51}$ Maryjej panny wziął. Abowiem chciał Bóg przez słowo swoje wszystko przywrócić i naprawić, co był przez słowo swoje sprawił i stworzył. Ono słowo wcielone jest „Mesyjasz” - on ludu izrahelskiemu w Zakonie obiecany, którego my Chrystusem zowiemy - co się rozumie, jeśli chcesz przełożyć, „pomazany”.

$\mathrm{Na}$ to słowo Boże wcielone, na tego Syna Bożego, na tego Chrystusa Bóg włożył wszystki nieprawości, wszystki uporne nieposłuszeństwa i wszystki ludzskie występki, chocia On był barzo niewinnym i od wszelakiego grzechu a występku wolnym a próżnym, którego tak ciężką i srogą kaźnią skarał, jakoby miał być nawinniejszym i jakoby tego, który by mógł być we wszystkich złościach i skargach przepart i przepokonan ${ }^{52}$, odjąwszy mu przez haniebną i srogą śmierć krzyżową żywot, który jako Adamów syn ${ }^{53}$ i jako człowiek cierpieniu poddany i śmiertelny miał, którego we wszystkich rzeczach posłusznego Bóg z martwych wzbudził i osławił ${ }^{54}$ a uwielbił, dawszy mu wszelaką władzą i moc na ziemi i na niebie. Po Chry-

Postanie Ducha Świętego

Co jest Duch Swięty stusowym do nieba wstąpieniu Duch Ś[więty] na apostoły zstąpił; na ty, mówię, które On, między ludźmi mieszkając, sobie był obrał i do siebie przyłączył.

On Duch Swięty jest boska i istotna ${ }^{55}$ miłość i życzliwość, przez którego umysły nasze duchownym żywotem otrzeźwia i ożywia Bóg, jako tym, który czujemy wiatrem abo tchem, bywają zachowane i otrzeźwione ciała nasze, póki żywot cielesny trwa.

50 prawie - prawdziwie.

$51 w$ zywocie - w łonie.

52 jakoby tego, który we [--] ztościach $i$ skargach przepart i przepokonan - sens: jakby był tym, któremu udowodniono grzechy i występki.

53 jako Adamów syn - jako człowiek. Mowa o ludzkiej naturze Chrystusa.

54 ostawit - uświetnił, uczcił.

55 istotna - rzeczywista, prawdziwa. 
Przy przyściu Ducha Świętego począł Bóg pełnić56 obietnice Abramowe, il ${ }^{57} \mathrm{w}$ Chrystusie z rodu a z plemienia Abramowego według ciała narodzonym pogani i narody, które wierzą Ewanjelijej, bierząą szczęście i błogosławieństwo. Abowiem ty same za plemię abo pokolenie Abramowe poczytamy, któremu samemu dziedzicstwo wszystkiego świata po zmartwychwstaniu sprawiedliwych należy ${ }^{59}$.

Wziąwszy Ducha Świętego, apostołowie poczęli o tym szczęśliwym a wesołym poselstwie kazać i uczyć na ten sposób, gdyż Bóg oczyścił nas wszystkich grzechy - w Chrystusie wszystki nam darmo bywaja przepuszczone.

A tak upominali wszystkich imieniem boskim, iżby wierzyli, iż przez imię Pana Chrystusowo byli z Bogiem pojednani, w którego to wesołego a fortunnego ${ }^{60}$ poselstwa obwieszczeniu jest zasadzon urząd apostoła, który nic inszego nie znaczy, tylko posła abo posłanego ${ }^{61}$. Tego odpuszczenia abo odpustu zupełnego oznajmienie i jawne obwieścienie zową Ewanjeliją, nad które poselstwo od początku świata ludzie nie słyszeli żadnego weselszego ani wdzięczniejszego ${ }^{62}$.

Którzykolwiek, tę wesołą nowinę wiarą przyjmując, wierzą, iż są z Bogiem zjednani, są synowie Abramowi, bo jako ten, wiarą się podparwszy, boskim obietnicom uwierzył, chocia się żadna przyczyna nadziewania $^{63}$ według baczenia a rozsądku ciała ${ }^{64}$ nie pokazowała. Tak oni też szczęśliwej nowinie, którą od Boga oznajmują i opowiadają, wiarę dawają, chocia się zacny znak i dowód nie ukazuje, na którym by wiara według baczenia a rozumu ludzskiego przestawała ${ }^{65}$, którą wszędzie ku temu wieśćc6 i przymuszać mamy, iżby Bogu posłuszna a powolna była.

56 petnić - spełniać.

57 ile - sens: o ile.

58 bierza - biorac.

59 Ty same za plemię [--] Abramowe poczytamy, któremu [--] dziedzicstwo [--] świata po zmartwychwstaniu [--] należy - sens: przez „plemię Abramowe” będziemy rozumieć tych, którzy zostaną zbawieni podczas Sądu Ostatecznego.

60 fortunnego - radosnego.

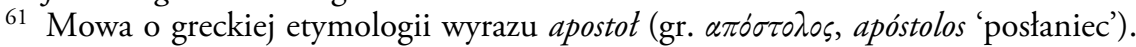

62 wdzięczniejszego - przyjemniejszego.

63 przyczyna nadziewania - powód do rozbudzenia nadziei.

64 wedtug baczenia a rozsądku ciata - sens: za pomocą zmysłów; por. $\mathrm{Rz}$ 8, 3-4.

65 na którym by [--] przestawata - o który opierałaby się.

66 ku temu wieść - nakłaniać do tego. 
Kościót Ile ich kolwiek jest w jednym Duchu zebranych i po wszystkim świecie zgromadzonych, którzy przyjąwszy tę Ewanjeliją, krzest przyjmują w imię Ojca i Syna, i Ducha Świętego, zową je Kościołem albo Zborem chrześcijańskim.

A którzykolwiek są w poczcie ${ }^{67}$ tego Kościoła, ile są członkami Chrystusowymi i wedle ducha się sprawują ${ }^{68}$, prawem sposobienia ${ }^{69}$ są syny Bożymi, sprawiedliwi, pobożni i święci, jako ci, którzy są wszystkich dóbr Pana Chrystusowych ucześnikami, które rzeczy w Nim są jako w głowie, a w nich jako w członkoch, zskąd je też chrześcijany zową, nad które imię żadne nie może być świętsze i zacniejsze, powiedziano $^{70}$.

Iż też wiara boska jest darem Bożym, o tę krom wszystkich inszych rzeczy $^{71}$ Boga pilnie i zapalczywymi ${ }^{72}$ prośbami prosić mamy, jako i apostołowie krzyczą i proszą: „Panie, przymnóż nam wiary"73. A przy tym niechaj wszyscy wiedzą, iże Bóg tego nie chce, iżbyśmy folgowali abo poddawali się przyrodzonemu niedowiarstwu abo nieprawemu dufaniu ${ }^{74}$, ale iżbyśmy się o to napilniej starali i o tym wszelaką pracą ${ }^{75}$ mieli, iżbyśmy głosowi, który słyszymy z Ewanjelijej, przyzwalali i na nim przestawali, jako jest napisano: Psal. 94 „Dziś, jeśli głos Jego słyszeć będziecie, nie chciejcie mieć serc twardych a zakamiałych"76, a głos też wiecznego Ojca to o Synie woła: „Tego słuchajcie!”77 I nie trzeba nic w tym pochybować ${ }^{78}$ i wątpić, iż to jest naprzednie<j>sze***, nawiętsze i nawyższe boskie rozkazanie.

Wtasność

A tej wiary ten jest własny urząd i powinowacstwo ${ }^{79}$ tę łaskę Ewanjelijej, to jest występków odpuszczenie i zjednanie z Bogiem dla

67 sq $w$ poczcie - sens: przynależą do wspólnoty.

68 wedle ducha się sprawuja - por. objaśn. 71.

69 sposobienia - przysposabiania dzieci, przyjmowania ich do rodziny.

70 Zob. Kol 2, 18-19, Ef 4, 15-16.

71 krom - oprócz.

72 zapalczywymi - gorącymi.

73 Zob. Łk 17, 5.

74 nieprawemu dufaniu - fałszywej wierze.

75 o tym wszelaka praca - wszelkie staranie o to.

76 zakamiatych - skamieniałych, przenośnie: nieczułych. Por. Ps 95[94], 7-8.

77 Zob. Mt 17, 5; Łk 9, 35; Mk 9, 7.

78 w tym pochybować - w to wątpić.

79 wiary [--] jest wtasny urząd a powinowacstwo - sens: powinność wynikająca $\mathrm{z}$ wiary. 
przyczyny, dla zastawiania ${ }^{80}$ i dosyć uczynienia Pana naszego Jezusa Chrysta, przyjąć i jakoby pojąć ${ }^{81}$.

A chrześcijański krzest to jest tym, którzy krzest przyjmują, co była arka Noego. Bo jako ten, dawając wiarę słowu Bożemu, wstąpiwszy do arki, był zachowan, tak i my, wierząc słowu Bożemu, które nam z Ewanjelijej oznajmują, przyjmując krzest, na Sądzie Pańskim będziem zachowani. A to nie dla krztu, ale wiarą, którą bywamy krzczeni.

A którzy są prawdziwi chrześcijani, snadnie je między inszymi ludźmi poznać $\mathrm{z}$ wielkiej a z gorącej między nimi miłości, która daleko inszych miłość przechodzi ${ }^{82}$, tak iż ta zobopólna miłość jest pewnym chrześcijańskiej wiary znakiem.

Ta to chrześcijańska wiara, która prawdziwa, od Boga natchniona i objawiona jest, ty czterzy skutki i owoce w tych, którzy wierzą, pokazuje i z siebie wypuszcza. Abowiem zapala ku temu, iż Boga miłować będziemy i ty rzeczy, które boskie są, też ku miłowaniu Chrystusa i wszystkich rzeczy, które są Chrystusowe, pobudza.

Nadto przynosi uspokojenie sumnienia, gdy o tym wie, iż jest z Bogiem pojednana. Przy tym uczy też tego, abyśmy się wszystkim dobrze zachowali ${ }^{83}$, ale osobliwie tym, którzy są tejże wiary ${ }^{84}$. Na ostatek umarza ${ }^{85} \mathrm{w}$ tych, którzy wierzą chuci a żądze grzechu.

A tak boska i Chrystusowa miłość, uspokojenie sumnienia, chrześcijańska miłość, ciała morzenie a hamowanie ${ }^{86}$ - pewne są owoce chrześcijańskiej wiary od Boga natchnionej. A tak jako jest własne dzieło słońca oświecać i zagrzewać ${ }^{87}$, tak iż nie ma być słońcem zwano, jeśli nie świeci a nie zagrzewa, tak nie mamy mieć ani nazywać tej wiary za chrześcijańską, która umysłów ku boskiej i Chrystusowej miłości nie pobudza, która sumnienia spokojnego nie czyni, która też chuci a żądzy grzechu nie umarza a nie hamuje.

Chrześcijańskiego człowieka to rzecz jest, iżby się wiecznego żywota $\mathrm{w}$ Ewanjeli<je>j $\mathrm{j}^{* * * *}$ obiecanego, zawżdy nie przestawając ${ }^{88}$,

80 zastawiania - wstawiennictwa.

81 jakoby pojąć - żeby zrozumieć.

82 daleko inszych mitość przechodzi - sens: dalece przewyższa miłość, którą mają inni.

83 się wszystkim dobrze zachowali - sens: wszystkim ludziom czynili dobrze.

84 są tejże wiary - sens: podzielają tę wiarę.

85 umarza - obumiera, niszczeje.

86 morzenie a hamowanie - opanowywanie, dyscyplinowanie.

87 tak jako jest wtasne dzieto stońca oświecać i zagrzewać - tak jak właściwe słońcu jest oświetlanie i ogrzewanie.

88 zawżdy nie przestawając - nigdy nie przestając. 
nadziewał ${ }^{89}$, pojąwszy na umyśle kstałt abo obraz stanu wiecznego żywota. Abowiem tak ty rzeczy, które są tego tutecznego żywota ${ }^{90}$, bez frasunku przetrwa, wiedząc, iż tu jest gościem, a za to mając, iż odzierży $^{91}$ dzierżawę wiecznego żywota.

Wzywanie Tego chrześcijańskiego człowieka wszystek żywot ma być ustawicznym wzywanim a prośbą ${ }^{92}$, którą zawżdy ${ }^{93}$ umysł tuż przy Bogu jest i stoi; też niechaj samego Boga i Chrystusa chwały szuka.

Też żywot jego ma być wiecznym postem, którym się będzie powciągał ${ }^{94}$ od tych rzeczy, które ciało przeciwko duchowi podburzają i ciągną, jako hojne potraw przebieranie i odmienianie ${ }^{95}$, zbytnie a dworne ciała ochędóstwo ${ }^{96}$, odmienne a zdradliwe świetskie rozkoszy a krotochwile ${ }^{97}$. Niechaj też będzie żywot jego świętem wiecznym, w którym by umysł z Bogiem zjednany zawżdy rozkosz, krotofile i wesele miał, która rzecz jest prawdziwe święto a wytchnienie abo odpoczynienie chrześcijańskie.

Modlitwa

Pańska

Prośba zwyczajna - pewnego czasu i głośna ${ }^{98}$ - chrześcijańska ta ma być, której Pan Chrystus swoich apostołów nauczył, każąc im prośby czynić na ten sposób: „Ojcze nasz, któryś jest w niebie” etc. ${ }^{99}$ A ta tak ma być mówiona, iżby umysł wszędzie chwały boskiej żądał, która by się łsnęła ${ }^{100} \mathrm{i}$ świeciła w tych, którzy Chrystusowę sprawiedliwość wiarą przyjmują, a iż ma być dobrze rzecz wiadoma, czego w prośbach chrześcijanin ma żądać, potrzeba, iżby dostatecznie wiedział i miał wszystki rzeczy z osobna, które w sobie ta święta prośba zawiera. Też chrześcijańskiego człowieka prośba ma się zawżdy wiarą

89 się wiecznego żywota [--] nadziewat - miał nadzieję na żywot wieczny.

90 rzeczy, które sq [--] tutecznego żywota - sens: sprawy, które są właściwe dla życia ziemskiego.

91 za to mając, iż odzierży dzierżawe żywota wiecznego - sens: w zamian otrzymując to, że dostąpi życia wiecznego.

92 wzywanim a prośbą - modlitwą.

93 którą zawżdy - sens: za pomocą której zawsze.

94 powciagat - powstrzymywał.

95 hojne potraw przebieranie i odmienianie - sens: wybieranie spośród obfitych i różnorodnych potraw.

96 zbytnie a dworne ciała ochędóstwo - zbytkowne i wystawne ozdabianie ciała.

97 odmienne [--] rozkoszy a krotochwile - przemijające rozrywki.

98 pewnego czasu i gtośna - sens: wypowiadana w określonym czasie i na głos.

99 której Pan Chrystus [--] nauczyt, każąc im prośby czynić w ten sposób: „Ojcze nasz..." - idzie o Modlitwę Pańską, której Chrystus nauczył apostołów; zob. Mt 6, 5-15.

100 by się tsnęta - błyszczałaby. 
podpierać, którą pewnie temu ma wierzyć, iż to wszystko uprosi, czego żąda. A to ma być na wielkiej baczności miano ${ }^{101}$, iżby chrześcijanin nie prosił tego, co nie jest w Świętym Piśmie obiecano. Abowiem obietnica podpiera i mocną czyni wiarę, która nie jest wiarą, jeśli się obietnicą Bożą podpierać i zastawiać102 nie będzie.

Jałmużna chrześcijańska ku Bożej i Chrystusowej chwale ma być obracana, co natenczas bywa, gdy tych podpomagać ${ }^{104}$ i ratować będziemy, którzy boskim i Chrystusowym obietnicom dufają. I gdy o tym pieczą i staranie mamy, aby ci, którzy nadzieje swoje w Bodze i w Chrystusie pokładają, w niej omelności żadnej nie poznali ${ }^{105}$, ale iżby tym więcej dufali, gdy od braciej rzeczami potrzebnymi będą opatrzeni.

Człowiek chrześcijański ma naśladować Chrystusa nawięcej, ile może, a w tych rzeczach, które są podobne ${ }^{106}$, to jest: w cichości ${ }^{107}$, którą nigdy nikomu nie zaszkodził; w pokorze, którą się uniżył, wziąwszy na się ciało człowiecze, a żywot wiodąc niski i pokorny; w miłości, którą On pobudzony za nieprzyjacioły umarł; w posłuszeństwie, które przeciwko wiecznemu Ojcowi aż do śmierci krzyżowej pokazał, to nam przywracając, co był Adam przez nieposłuszeństwo utracił. A tak należy chrześcijańskiemu człowiekowi Pana Chrystusowych skutków a uczynków naśladować i tego się, czego Chrystus nie czynił, wystrzegać, a to niechaj będzie jakoby jaki snur a wzór, według którego wszystek żywot chrześcijański wieść mamy.

A iżby mógł kto ku temu przyść, iżby chrześcijański żył ${ }^{108}$, nic nie jest do tego lepszego, możniejszego i dzielniejszego ${ }^{109}$, jedno iżby o tym staranie miał, iżby co dalej, tym więcej dzień pole dnia ${ }^{110}$ brał rozmnożenie i pochop ${ }^{111} \mathrm{w}$ wierze, bo ta jest on ogień, który pali i trawi wszystki Adamowych niedostatków ostatki i czyni żywot wesoły, wdzięczny i spokojny.

101 na wielkiej baczności miano - sens: potraktowane ze szczególną uwagą.

102 obietnica [--] zastawiać - opierać się na obietnicy.

103 Eleemosyna - łac. jałmużna, dar.

104 podpomagać - wspierać.

105 w niej omelności żadnej nie poznali - sens: nie doznali niczego, przez co uznaliby swoją wiarę za błąd.

106 podobne - możliwe do zrobienia.

107 cichości - łagodności, cierpliwości.

108 chrześcijański żyt - sens: żył po chrześcijańsku.

109 możniejszego i dzielniejszego - pewniejszego i skuteczniejszego.

110 dzień pole dnia - dzień po dniu.

111 pochop - gorliwość. 
Chrześcijanów też prośba na to się ma nawięcej oględać, iżby przez nie dla Chrystusowego posłuszeństwa to wszystko naprawił, co był przez nieposłuszeństwo Adamowe utracił, abowiem, utraciwszy ten obraz i kstałt boski, był $\mathrm{z}$ raju wygnan. A niechaj temu wierzy, iż przez Chrystusowe posłuszeństwo obraz i kstałt boski naprawi ${ }^{112}$ i przystęp ${ }^{113}$ do Jego królestwa, które jest raj niebieski, częścią ${ }^{114}$ na tym świecie, jako wzięt a pojęty może być115, częścią też $\mathrm{w}$ wiecznym żywocie, jako tam już prawie wzięt a dosięgnion ${ }^{116}$ będzie, sobie zjedna i sposobi ${ }^{117}$.

Chwalenie Też to chrześcijańskiemu człowiekowi przystoi i należy, iżby Boga chwalił w Duchu i w prawdzie wszystki Boże sprawy i dzieła jako dobre, sprawiedliwe, święte pochwalał. A z tych nic nie ganić, które chocia szczęśliwe, chocia przeciwne i niefortunne przypadną ${ }^{118}$.

Zmartwych-

wstanie

umartych

Gdy czas od Boga naznaczony przyjdzie, Chrystus przyjdzie z chwałą i z majestatem sądzić żywe i umarłe, które wielką mocą boską z martwych wzbudzi. $\mathrm{Na}$ tym sądzie pospolitym ${ }^{119}$, ile ich kolwiek będzie, którzy łaski Ewanjelijej, która im była oznajmiona i podana,

Boży wiarą nie przyjęli, będą na wieczne karanie jako Boży nieprzyjaciele nieprzyjaciele i ci, którzy słowem Jego gardzili, zskazani. A którzykolwiek wziąwszy łaskę Ewanjelijej, krzest też przyjęli, wiecznego i szczęśliwego żywota dostaną.

W którym szczęściu i chwale chrześcijani wiecznie mieszkać będą z Chrystusem, używając Boga i Chrystusa, i żywiąc z Nimi. Bo natenczas Boga i Chrystusa dostatecznie i doskonale oglądają i poznają, jako ich teraz zna i widzi Bóg a Chrystus.

Tej nauki chrześcijańskiej pewność i prawda nie skądinąd jest wzięta, tylko z Starego i Nowego Zakonu, które gdy z Ducha Świętego są napisane ${ }^{120}$, jest tego potrzeba, iżby im chrześcijanin wierzył zawżdy i wszędzie nie inaczej, jedno jako samemu Bogu, i to za

112 obraz $i$ kstatt boski naprawi - sens: przywróci częściowo utracone (przez grzech) podobieństwo Bogu.

113 przystęp - wstęp.

114 częścia - częściowo.

115 jako wzięt a pojęty może być - sens: tyle, ile może być ogarniony i zrozumiany.

116 prawie wzięt a dosięgnion - prawdziwie ogarniony i osiągnięty.

117 sposobi - pozyska.

118 chocia szczęśliwe, chocia przeciwne [--] przypadna - czy trafią się pomyślne, czy niepomyślne.

119 pospolitym - powszechnym.

120 z Ducha Świętego [--] napisane - sens: napisane za natchnieniem Ducha Świętego. 
pewne ${ }^{121}$ wiedział, iż natenczas Boga słucha, kiedykolwiek co słyszy abo czyta z Pisma Świętego.

\section{Rzecz ku chrześcijańskim rodzicom}

A przetoż czyńcie około tego pilnośćc ${ }^{122}$ wy, rodzicy, którzykolwiek potomki swoje ku chwale boskiej wychować chcecie. Proszę też was, chciejcie dobrze wyćwiczyć i wyprawić dziatki swoje w tej boskiej i Chrystusowej nauce, $\mathrm{w}$ tym to stanie chrześcijańskim. A o tym ma być nawiętsze staranie, wnet $\mathrm{z}$ dzieciństwa ${ }^{123}$ i gdy już dziatki poczynają podrastać, według ich dowcipu ${ }^{124}$ iżby ich tego uczono, co należy żywotowi prawie chrześcijańskiemu ${ }^{125}$, to jest jako o przeźrzeniu Bożym ${ }^{126}$, o Wieczerzy Pańskiej, o onej świętej a wielkiej tajemnicy Trójce Świętej mają rozumieć i dzierżeć ${ }^{127}$. A jeśli się tak, jako was tu upominam, zachować ${ }^{128}$ będziecie, dwa pożytki wam stąd urostą. Jeden, iż fałszywą nauką nie będą mogli być zwiedzieni już dorośli. Drugi, iż bez wszelakiej pracej prędko i chutliwie ${ }^{129}$ się ku prawdziwej nauce i prawemu pobożeństwu udadzą i nakłonią, kiedykolwiek za wolą boską, ze wnętrznym wezwanim ${ }^{130}$ będą powołani ku łasce Ewanjelijej, iżby zupełny odpust ${ }^{131}$ i wszystkich występków przepuszczenie otrzymali dla sprawiedliwości, której Bóg srogo dokazał nad Synem ${ }^{132}$ swoim własnym Jezusem Chrystem, Panem naszem, któremu niechaj będzie cześć i chwała na wieki. Amen.

\section{Do tego, kto będzie czedł Ostafi Trepka}

Nic w tym nie trzeba wątpić, iż ten katechizm będzie się tobie barzo krótki i niedostateczny widział. Ale gdy mu się pilnie przypatrzysz

121 za pewne wiedziat - uznał za niewątpliwe.

122 czyńcie okoto tego pilność - sens: dbajcie, starajcie się o to.

123 wnet z dziecinstwa - sens: od razu od najmłodszych lat.

124 wedtug ich dowcipu - zgodnie z ich pojętnością, możliwością zrozumienia.

125 co należy żywotowi prawie chrześcijańskiemu - sens: czego wymaga prawdziwie chrześcijański żywot.

126 przeźrzeniu Bożym - słowie Bożym.

127 dzierżeć - sądzić.

128 zachować - postępować.

129 chutliwie - chętnie.

130 ze wnętrznym wezwanim - sens: z wewnętrznych, duchowych pobudek.

131 zupetny odpust - całkowite odpuszczenie.

132 dla sprawiedliwości, której Bóg dokazat nad Synem - sens: ze względu na karę, na jaką Bóg skazał Syna. 
i to, co jest w nim krótko napisano, uważysz ${ }^{133}$, zaprawdę to najdziesz i obaczysz, iż to wszystko z Starego i z Nowego Zakonu weń jest zniesiono ${ }^{134}$, co nie tylko małym dziatkom, ale też ludziom dorosłym i w leciech podeszłym ${ }^{135}$ potrzeba ku zbawieniu wiedzieć. Bo nie tylko mliekiem może być nazwan młodym dziatkom, ale też całym i dostatecznym pokarmem dorosłym i letnim ${ }^{136}$ ludziom; czego słowy nie trzeba ozdabiać, bo ci, którzy już nauki chrześcijańskiej wiadomość mają i na potym ku łasce Ewanjelijej będąc powołani, mieć będą, tego samą rzeczą dojdą ${ }^{137}$.

Tak hojne i kosztowne boskie potrawy Vergerius, mąż Boży i Chrystusów służebnik (dla którego majętności i dostojeństwa opuścił ${ }^{138}$ i wolał być z Mojzeszem ubogim i niskim w Kościele Pańskim niżli w pałacoch niepobożnych mieszkać, a wszystkich rzeczy dostatek i obkwitość mieć) tobie za wielkim staranim i pilnością omyślawa ${ }^{139}$. Przeto tobie należy i przystoi to jemu wszelaką wdzięcznością oddziaławać ${ }^{140}$ i jego wszystki przedsięwzięcia pobożne a chrześcijańskie Bogu pilnymi prośbami zalecać etc.

\section{Bibliografia}

\section{Źródła}

Brenz J., Catechismus to jest Zupetna nauk chrześcijańska [--] który możesz dobrze mata Biblija nazwać, tł. O. Trepka, Królewiec 1556

Hubatsch W., Geschichte der evangelischen Kirche Ostpreussens, Bd. 3: Dokumente, Göttingen 1968

Karłowicz J., Mleko duchowne z r. 1556, „Prace Filologiczne”, 1, 1885, s. $404-433$

Luther M., Enchiridion. Catechismus maty prze plebany $i$ kaznodzieje niedouczone i lud prosty, tł. J. Radomski, Królewiec 1562

Malecki J., Catechismus, to jest Nauka krześcijańska od apostotów dla prostych ludzi we trzech czastkach zamkniona, Królewiec 1546

133 uważysz - spostrzeżesz.

134 jest zniesiono - zostało zgromadzone.

$135 w$ leciech podesztym - w podeszłym wieku.

136 letnim - starym.

137 sama rzeczq dojdq - sens: zrozumieją bez dodatkowych wyjaśnień i upiększeń.

138 majętności i dostojenstwa opuścit - mowa o porzuceniu przez Vergeria w 1549 r. godności biskupa Capodistrii we Włoszech (współcześnie miasta Koper w Słowenii).

139 omyślawa - obmyśla.

140 oddziatawać - odpłacać. 
Seklucjan J., Catechismus, to jest Krótka, prosta starej wiary chrześcijańskiej nauka, Królewiec 1549

Seklucjan J., Catechismus, to jest Nauka naprzedniejsza i potrzebniejsza ku zbawieniu o wierze krześcijańskiej, Królewiec 1547

Seklucjan J., Simplex textus catechismi. Katechizmu tekst prosty dla prostego ludu, Królewiec 1545

Valdés J. de, Instrucion cristiana para los niños por Juan de Valdés en ocho lenguas / Christliche Kinderlehere, hrsg. E. Böhmer, Bonn 1883

[Valdés J., Vergerio P. P.], Ein edel schriftlich Kleinath und Verehrung, tł. B. Hagen, Tübingen 1555

[Valdés J., Vergerio P. P.], Illustri atque optimae spei puero Eberhardo, illustrissimi principis et domini, domini Christophori Ducis Wirtembergensis etc., filio primogenito, munusculum Vergerii exulis Iesu Christi, [Tübingen] 1554

[Valdés J., Vergerio P. P.], Lac spirituale pro alendis ac educandis Christianorum pueris ad gloriam Dei. Munusculum Vergerii [--] Domino Nicolao, [--] principis D. Nicolai Radivili [--] primogenito. Adiecta sunt: Prima christianae religionis elementa [--] per Andream Tricesium [--] et Mathiam Stoium, Königsberg [1554-1556?]

[Valdés J., Vergerio P. P.], Lacte spirituale, col quale si debbono nutrire e allevare i figliuoli de christiani in gloria di Dio, Basilea 1549

[Valdés J., Vergerio P. P.], Latte spirituale, col quale si debbono nutrire e allevare i figliuoli de Christiani in gloria di Dio, Pavia 1550

[Valdés J., Vergerio P. P.], Upominek, który Vergerius jasnemu panu Mikotajowi [--] postat - Mlieko duchowne dla karmienia $i$ wychowania chrześcijańskich dziatek ku chwale boskiej, tł. O. Trepka, Królewiec 1556

Bazy bibliograficzne

EDIT 16 - Censimento nazionale delle edizioni italiane del XVI secolo, http:// edit16.iccu.sbn.it (25 XII 2020)

VD 16 - Verzeichnis der im deutschen Sprachbereich erschienenen Drucke des 16. Jahrhunderts, http://www.vd16.de (25 XII 2020)

\section{Opracowania}

Bock V., Die Anfänge des polnischen Buchdrucks in Königsberg. Mit einem Verzeichnis der polnischen Drucke von Hans Weinreich und Alexander Augezdecki, w: Königsberger Buch-und Bibliotheksgeschichte, hrsg. A. E. Walter, Köln 2004, s. 127-156

Böhmer E., Bibliotheca Wiffeniana. Spanish Reformers of Two Centuries from 1520, vol. 1, Strassburg 1874

Buchwald-Pelcowa P., Aleksander Augezdecki. Królewiec - Szamotuty, 1549-1561(?), Wrocław 1972 (Polonia Typographica Saeculi Sedecimi, t. 7)

Chojnacki W., Bibliografia polskich druków ewangelickich Ziem Zachodnich i Pótnocnych 1530-1939, Warszawa 1966 
Chojnacki W., Szymańska-Jasińska M., Uzupetnienie do „Bibliografii polskich druków ewangelickich Ziem Zachodnich i Pótnocnych 1530-1939”, „Komunikaty Mazursko-Warmińskie”, 1997, 2, s. 271-285

Drukarze dawnej Polski od XV do XVIII wieku, t. 4: Pomorze, oprac. A. Kawecka-Gryczowa, K. Korotajowa, Wrocław 1962

Estreicher K., Bibliografia polska, t. 32, Kraków 1938

Jobes K. H., „Got Milk?”. A Petrine Metaphor in 1 Peter 2.1-3 Revisited, „Leaven”, 20, 2012, 3, s. 1-6

Krókowski J., Wstęp, w: A. Trzecieski, Carmina. Wiersze tacińskie, oprac. J. Krókowski, Wrocław 1957, s. XVII-XLIII

Małłek J., Reformacja i protestantyzm w Polsce i Prusach (XVI-XX w.), Toruń 2012

Nieto J. C., Juan de Valdés on Catechetical Instruction. The Dialogue on Christian Doctrine and the Christian Instruction for Children, „Bibliothèque d'Humanisme et Renaissance", 36, 1974, 2, s. 253-272

Pierce R. A., Pier Paolo Vergerio. The Propagandist, Roma 2003

Ptaszyński M., Reformacja w Polsce a dziedzictwo Erazma z Rotterdamu, Warszawa 2018

Renaissance Paratexts, ed. H. Smith, L. Wilson, Cambridge 2011

Reu J. M., Quellen zur Geschichte des Katechismus-Unterrichts, Bd. I/3,1a, Güttersloh 1927

Rospond S., Studia nad jezykiem polskim XVI wieku (Jan Seklucjan, Stanistaw Murzynowski, Jan Sandecki-Malecki, Grzegorz Orszak), Wrocław 1949

Sembrzycki J., Die Reise Vergerius nach Polen 1556-1557, sein Freundkreis und seiner Königsberger Flugschriften aus dieser Zeit, Königsberg 1890

Winiarska-Górska I., Staropolskie ewangelickie katechizmy $i$ kancjonaty jako ksiażki formacyjne, w: Ewangelicyzm reformowany w Pierwszej Rzeczypospolitej. Dialog z Europa i wybory aksjologiczne w świetle literatury i piśmiennictwa XVI-XVII wieku, red. D. Chemperek, Warszawa 2015, s. 133-169

Winiarska-Górska I., Szesnastowieczne przekłady Pisma Świętego na język polski (1551-1599) jako gatunek nowożytnej ksiązki formacyjnej, Warszawa 2017

Wotschke T., Eustachius Trepka. Ein Prediger des Evangeliums in Posen, „Zeitschrift der Historischen Gesellschaft für die Provinz Posen”, 18, 1903, s. $87-144$

\section{Spiritual Milk - A Gift from Pietro Paolo Vergerio in the Polish Translation by Ostafi Trepka of 1556}

This article serves to present the Polish edition of a catechetical work by Juan Valdés addressed to children, known as Spiritual Milk (1556); its Latin version had been previously edited by Pietro Paolo Vergerio as Lac spirituale 
(1554). This text consists of two parts: a preliminary study of the work and its critical edition.

The first part recapitulates the bibliographical information on the print in the context of other editions, presumably controlled by Vergerio, published between 1554 and 1556. The introduction discusses the problems that make it possible to understand the context in which the Polish translation appeared: the genre of the text, the place of the Polish edition within other catechetical publications issued in Königsberg around the mid-sixteenth century, the question of the target audience of the Polish translation (to which the Polish translator included adults in addition to children), and the issue of typographical and paratextual solutions used together with their impact on the functionality of the text materialised in print.

The second part presents a transcription of the text with a commentary made according to the contemporary practices of critical editing applied to Old Polish literary texts. It is preceded by a presentation of the edition rules and principles, which also gives the most crucial information about the edition's basis and summarises the main linguistic characteristics of the transcribed text.

Wojciech Kordyzon - asystent na Wydziale Polonistyki Uniwersytetu Warszawskiego, w latach 2019-2021 pracował na Wydziale „Artes Liberales" w ramach konsorcjum RESILIENCE (Religious Studies Infrastructure: Tools, Experts, Connections and Centers). Kieruje indywidualnymi projektami badawczymi: Więcej niż propaganda. Polskojezzyczny program wydawniczy $w$ Królewcu jako projekt edukacji religijnej i kulturalnej (ok. 1544-1575) (Narodowe Centrum Nauki, nr 2020/37/N/HS2/00467) oraz Stulecie sporu, stulecie dialogu. Bernardino Ochino i protestancki dialog polemiczny $w$ Polsce XVI wieku (program MNiSW „Diamentowy Grant”, nr DI2016003546).

Wojciech Kordyzon - research assistant at the Faculty of Polish Studies, University of Warsaw; in 2019-2021 he worked within the RESILIENCE (Religious Studies Infrastructure: Tools, Experts, Connections and Centers) consortium at the Faculty of 'Artes Liberales'. The PI of individual research projects: Beyond Propaganda: Polish Publishing Programme in Königsberg as a Project of Religious and Cultural Education (ca. 1544-1575) (Narodowe Centrum Nauki, no. 2020/37/N/HS2/00467) and Age of Controversy, Age of Dialogue: Bernardino Ochino and Protestant Polemical Dialogue in Sixteenth-Century Poland („Diamentowy Grant” programme financed by the Ministry of Science, no. DI2016003546).

E-mail: wojciech.kordyzon@uw.edu.pl 